ISSN: 0212-0267

DOI: http://dx.doi.org/ro.I420I/hedu20I534305336

\title{
MOVIMIENTO POPULAR \\ Y ESCUELA EN EL FRANQUISMO: LAS IKASTOLAS EN GIPUZKOA ${ }^{1}$
}

\section{Popular movement and school in the Franco regime: the «ikastolas» in Gipuzkoa}

Iñaki Zabaleta, Joxe Garmendia e Hilario Murua Cartón

Euskal Herriko Unibertsitatea/Universidad del País Vasco

Correo-e: i.zabaleta@ehu.es; joxe.garmendia@ehu.es; hilario.murua@ehu.es

Recepción: Is de enero de 20I4. Envío a informantes: 30 de marzo de 2014.

Fecha de aceptación definitiva: I de junio de 20I4

Resumen: Los modos de lucha y resistencia frente al franquismo presentan una enorme variabilidad y las motivaciones que las activan (políticas, sociales, culturales...) se caracterizan por su gran heterogeneidad. El ámbito educativo cobra una especial significación en Euskal Herria, desde la perspectiva de la cultura vasca y el euskera, con todas sus derivaciones, incluida la identidad nacional. En ese sentido, la hipótesis central de nuestra aportación es que el surgimiento y posterior desarrollo del movimiento de ikastolas, de los años sesenta y setenta, hay que situarlo en un contexto amplio de lucha popular. Este trasciende el terreno puramente escolar para penetrar y activar todo el tejido social vasco, donde se desplegarán múltiples estrategias reactivas y alternativas al modelo educativo franquista. Para ello contextualizaremos el fenómeno en la realidad social, económica, política y educativa del periodo. También contaremos con la documentación existente en archivos y el testimonio directo de significados protagonistas del movimiento popular.

Palabras Clave: identidad nacional; lengua vasca; País Vasco; franquismo; educación popular; ikastola.

I Esta aportación es resultado de un proyecto de investigación financiado por el Ministerio de Educación y Ciencia, proyecto número EDU-20IO-I52I8. Los autores son miembros del Grupo de Estudios Históricos y Comparados en Educación-Garaian, reconocido por el Gobierno Vasco con el número IT 603-I3 y de la Unidad de Formación e Investigación «Educación, Cultura y Sociedad (UFI II/54)» de la Universidad del País Vasco/Euskal Herriko Unibertsitatea UPV/EHU. 
AвsTRACT: The ways of struggle and resistance against the Franco regime present an enormous variability and the motivations which activate them (political, social, cultural...) are characterized by their great heterogeneity. The educational area receives a special significance in Euskal Herria, from the perspective of the Basque culture and the Basque language, with all its derivations, included the national identity. In this sense, the central hypothesis of our contribution is that the emergence and later development of the movement of the 'ikastolas' of the sixties and seventies must be placed in a wide context of popular fight. This transcends the school area in order to penetrate and activate the whole Basque social fabric, where multiple reactive strategies and alternatives the educational pro-Franco model will spread out. For all this, we will have to provide a context for the phenomenon taking into account the social, economic, political and educational reality of the period. We will also count on the existing documentation in several Archives and the direct testimony of some of the main protagonists of the popular movement.

Key words: National identity; Basque language; Basque Country; Franco regime; popular education; ikastola.

\section{Introducción}

$\mathrm{E}$ L ALZAMIENTO FASCISTA DE JULIO DE 1936 y la guerra que concluyó con la derrota de los defensores de la legitimidad democrática de la República española en 1939 tuvieron, también en el ámbito educativo, un impacto brutal. Los últimos años de la década de los treinta cerraron un ciclo de esperanza abierto por una sucesión de reformas, que abarcaba desde el reconocimiento de los derechos de los ciudadanos hasta la propia concepción del Estado ${ }^{2}$, para dar paso a un largo periodo donde la omnipresencia del Estado franquista y la Iglesia católica condicionarán la formación de varias generaciones ${ }^{3}$. También en el País Vasco, y más concretamente en lo que se refiere a la enseñanza del euskera y en euskera y a la enseñanza de la cultura vasca (pilares que definirán de forma particular a las ikastolas en el periodo que vamos a abordar), los efectos serán radicalmente contundentes abriéndose las puertas a un ciclo que, en ese sentido, se caracterizará por borrar, también en la escuela, todo rastro de identidad cultural vasca.

La defensa de una escuela en el País Vasco que atendiera a las características culturales y lingüísticas específicas de este territorio es previa a la llegada de la Segunda República española. Tendríamos que remontarnos incluso al siglo xIx; especialmente dentro de lo que se ha dado en conocer como Renacimiento Cultural

DÁvila, P.: «Nacionalismos y políticas educativas durante el siglo xx: de la centralización a la descentralización», en DÁvila, P. (coord.): Las políticas educativas en el País Vasco durante el siglo $X X$, Madrid, Biblioteca Nueva, 2004, p. 65.

3 También han sido analizadas más de trescientas entrevistas a las que se puede acceder en ahotsak.com, que brinda un enorme fondo de testimonios orales donde el ámbito educativo está contemplado junto a otros (familia, ocio, vida cotidiana, cultura, tradiciones, lengua, economía, política, etc.). 
Vasco (Euskal Pizkundea) constituye uno de sus fundamentos básicos ${ }^{4}$. Desde un punto de vista político, ya en los mismos orígenes del nacionalismo vasco, forma parte de una reivindicación de cuya insistencia serán testigo las primeras décadas del siglo siguientes. También instituciones culturales como la Asociación Euskara de Nabarra (1878) o, posteriormente, la Sociedad de Estudios Vascos/ Eusko Ikaskuntza, creada en I9I8 por las cuatro diputaciones vascas del País Vasco peninsular, harán bandera de esa defensa ${ }^{6}$. No faltarán, incluso, iniciativas -de carácter privado y público- que se traducirán en experiencias que materializarán la aspiración largamente alimentada de crear una escuela vasca donde el euskera y la propia cultura del País tuvieran cabida. Es el caso de la escuela fundada por Resurrección María de Azkue (Euskal Ikastetsea) a finales de la década de los noventa del siglo xIx, las Escuelas Vascas creadas a principios del siglo xx en Bilbao o aquellas primeras ikastolas que surgirán a lo largo de todo el territorio vasco durante el primer tercio del mismo, incluso las Escuelas de Barriada de Bizkaia -obra de la Diputación- o el trabajo desplegado en las Escuelas Rurales de Gipuzkoa -responsabilidad también de la máxima institución provincial- ${ }^{7}$. No se puede tampoco ignorar, ya dentro del periodo republicano, la creación de las Escuelas Vascas organizadas en torno a Euzko Ikastola Batza (Federación de Escuelas Vascas) y de las que más tarde se hará cargo el Gobierno Vasco surgido una vez iniciada la contienda bélica, o la misma aprobación del Estatuto de Autonomía, lo que es especialmente relevante a los efectos de brindar un marco jurídico, político y administrativo -en el contexto de descentralización del Estado y del sistema educativo español- que hiciera posible una enseñanza de características específicas en el País Vasco ${ }^{8}$.

Proyectos, experiencias, esperanza de futuro..., todo queda barrido a sangre y fuego por el fascismo victorioso que inaugurará un régimen dictatorial de larga vida con el sorprendente consentimiento -cuando no complicidad- de la comunidad internacional, a la que inútilmente se esperó para poder restituir la legalidad democrática republicana. El franquismo resultó implacable ejerciendo, también

4 Dávila, P.: La política educativa y la enseñanza pública en el País Vasco (I860-1930), Donostia, Ibaeta Pedagogía, 1995.

ZABALETA, I.: Euskal nazionalismoa eta hezkuntza (I895-1923), Leioa, Universidad del País Vasco/Euskal Herriko Unibertsitatea, 1998.

6 Estornes, I.: La Sociedad de Estudios Vascos. Aportación de Eusko Ikaskuntza a la cultura vasca (I8I8-1936), Donostia, Eusko Ikaskuntza, I983.

Dávila, P. y Zabaleta, I.: «Euskal eskolaren lehen urratsak», Tantak, n. ${ }^{4}$ (1990), pp. 2I3I. Zalbide, M.: «Euskal eskola, asmo zahar bide berri», en Euskal Eskola Publikoaren Lehen Kongresua, Vitoria-Gasteiz, Servicio Editorial del Gobierno Vasco, I990, pp. 2II-27I. ArRien, G.: Educación y escuelas de Barriada de Bizkaia (Escuela y Autonomía I898-1936), Bilbao, Diputación Foral de Bizakaia, 1987. GaRmendiA, J.: La enseñanza rural en Gipuzkoa. La labor de la Diputación y los ayuntamientos (1900-1959), Leioa, Universidad del País Vasco/Euskal Herriko Unibertsitatea, 2004. DÁvila, P. y ZabaleTA, I.: «La política educativa de las diputaciones vascas: entre proyectos y subvenciones», en Dávila, P.: 2004, op. cit., pp. I43-190.

8 Arríen, G.: La generación del exilio. Génesis de la Escuelas Vascas y las colonias escolares, Bilbao, Onura, 1983. Rekalde, I.: «La educación durante la segunda república en el País Vasco», en Dávila, P.: op cit., 2004, pp. I9I-250. Sebastián, L.: Entre el deseo y la realidad. La gestión del Departamento de Cultura del Gobierno Provisional de Euzkadi/1936-1937), Oñati, Instituto Vasco de Administración Pública, 1994. 
en lo que a la educación se refiere, una dominación que en el caso del País Vasco empujó al limbo de una larga espera a aquellas aspiraciones a las que, en el terreno de la enseñanza, tratará de dar respuesta el movimiento de ikastolas, ya a partir de la década de los sesenta. La depuración del magisterio que sigue a la victoria del general Franco 9 acompañará al retorno del centralismo que tradicionalmente ha caracterizado al sistema educativo español, junto a la uniformización de las enseñanzas donde no habrá sitio para otras lenguas o culturas que no sea la española. La cárcel, el exilio o la vigilancia atemorizante del régimen acompañarán a aquellos que buscaron el desarrollo de una educación que desde claves vasquistas ya no tendrá cabida en el escenario del nacional-catolicismo característico del franquismo $^{10}$. La Iglesia, especial beneficiaria de las transformaciones que empezará a conocer la década de los cuarenta del pasado siglo, mostrará, también en ese sentido, una complicidad absoluta con el nuevo Estado quien, significadamente a partir de la ley Educación Primaria de 1945, privilegiará su posición en el terreno de la enseñanza hasta el extremo de reducir la intervención, efectiva y potencial, del propio Estado, si bien el principio de subsidiariedad no supondrá en absoluto la inhibición respecto al control ideológico de la escuela ${ }^{\text {II }}$.

No obstante la implacable persecución del euskera por parte del franquismo -con sus consiguientes efectos también en el terreno escolar- ${ }^{12}$, no faltará quien en las sombras de la clandestinidad trazará un puente entre las experiencias y proyectos de preguerra y la eclosión del movimiento de las ikastolas a partir de los años sesenta. Será justamente en Gipuzkoa, territorio donde situamos el análisis objeto del presente trabajo, donde con lo que la profesora Fernandez ha dado en denominar etxe-eskolak (escuelas domésticas) toma cuerpo «la expresión escolar vasca más temprana de la posguerra» $»^{13}$. La referencia a Elbira Zipitria -a quien diferentes autores consideran iniciadora del movimiento de ikastolas $-^{14}$ resulta obligada para entender la aparición a partir de 1946 de este tipo de escuelas: andereño (maestra) antes de la guerra en la Escuela de Muñoa en San Sebastián y militante destacada de la organización de mujeres nacionalistas vascas Emakume Abertzale Batza, inicia la creación de escuelas localizadas en pisos particulares junto a otras colaboradoras, extendiendo este tipo de experiencia a otros pueblos

9 Navarro, R.: «El franquismo, la escuela y el maestro (1936-75)», Historia de la Educación, n. ${ }^{\circ}$ 8 (1989), pp. 167-I80. Ostolaza, M.: El garrote de la depuración. Maestros vascos en la guerra civil y el primer franquismo, Donostia, Ibaeta, 1996.

to Barreiro, H.: «Nacional-catolicismo y educación en la España de posguerra», Historia de la Educación, n. ${ }^{\circ}$ I4-I5 (1995/96), pp. 417-432. CÁmARA, G.: Nacional-catolicismo y escuela. La socialización política del franquismo (I936-I95I), Jaen, Hesperia, 1984. Gervilla, E.: La escuela del nacional-catolicismo. Ideología y educación religiosa, Granada, Impredisur, I99o. Navarro, R.: La enseñanza primaria durante el franquismo (1936-1975), Barcelona, PPU, 1990.

II Fernández, J. M.: Estado y educación en la España contemporánea, Madrid, Síntesis, 2002, p. I40.

12 Torrealdai, J. M.: El libro negro del euskara, Donostia, Ttartalo, 1998.

13 Fernández, I.: «La escuela vasca y la larga historia de la posguerra», en Dávila, P. (coord.): Lengua, escuela y cultura. El proceso de alfabetización en Euskal Herria, siglos XIX y XX, Bilbao, Euskal Herriko Unibertistatea/Universidad del País Vasco, 1995.

${ }^{14}$ Garmendia, M. C.: Les ikastolas en Pays Basque d'Espagne. La question du bilinguisme scolaire, Estrasburgo, Tesis doctoral inédita, 1985. BAsURKo, F.: «La normalización de la ikastola: breve historia y estado de la cuestión de la Escuela Pública Vasca», Historia de la Educación, n. ${ }^{\circ} 8$ (1989), pp. 139-165. 
del territorio guipuzcoano. Las etxe-eskolak conforman un modelo de escuela -limitado, ciertamente- localizado en un espacio privado donde la enseñanza en euskera se hace efectiva desde parámetros ideológicos, incluso organizativos, contextualizables en el periodo de preguerra, marcadamente diferente a las transformaciones sociales, políticas y culturales que explican el surgimiento y posterior desarrollo del movimiento de las ikastolas ${ }^{15}$.

Por otra parte, las ikastolas han despertado, en el ámbito concreto de la historia de la educación del País Vasco, el interés de muchos investigadores. Los estudios disponibles -y a los que obviamente habremos de referirnos a lo largo de nuestro trabajo- nos permiten disponer de aportaciones que brindan análisis diversos que posibilitan la construcción de un marco interpretativo de un fenómeno, no reducible exclusivamente al terreno escolar y que ha alcanzado un protagonismo sobresaliente en la realidad histórica reciente del País Vasco. Situando el marco territorial de nuestro trabajo en Gipuzkoa, trataremos -como ya ha sido realizado en otros ámbitos, como el sociológico- de caracterizar el movimiento de las ikastolas a lo largo de las décadas de los sesenta y los setenta en el marco de un proceso de construcción histórica donde parámetros de escuela pública/escuela privada resultan insuficientes -si no perversos- en el momento de entender los procesos de creación y desarrollos escolares de determinados contextos sociales y culturales. De facto, si algo podemos constatar es el hecho de que históricamente, tal y como recuerda Rodríguez ${ }^{16}$, el modelo ikastola se ha reivindicado a sí mismo como enseñanza pública. En ese sentido, atender a cuestiones tales como el de la titularidad de las ikastolas en relación a un movimiento que supera los límites de la pura iniciativa privada, la misma apuesta pedagógica por la que se inclina, incluso los modos, estrategias y estructuras organizativas de los que se dota o, yendo más allá, la propia mirada y actitud vigilante -cuando no beligerante- del propio Estado nos facilitarán la comprensión de ese movimiento en términos más pertinentes.

\section{Público/privado: la cuestión de la titularidad de las ikastolas}

El silencio, esa especie de exilio interior -tal y como constata Dávila- ${ }^{17}$ al que estuvo condenada la aspiración a una escuela que, lejos del modelo escolar triunfante del franquismo, diera cabida a la cultura vasca y, especialmente, a la enseñanza del y en euskera, se romperá. Las primeras voces que podían escucharse en las etxe-eskolak inician la posibilidad de abrir una brecha en el muro impuesto por la dictadura. En cualquier caso, en un contexto que cabe identificar como de superación de un planteamiento de mera resistencia -en muchos casos reducido prácticamente al ámbito privado- para pasar a la defensa activa de un modelo

15 FERnÁndeZ, I.: op. cit., pp. 163-175.

16 Rodríguez, F.: Construir o destruir naciones. El sistema educativo en el País Vasco, Bilbao, Besatari, 1999, p. 87.

17 DÁvila, P.: «Escuela y magisterio vascos: dos grandes ejes de la enseñanza primaria», en DÁvila, P. (coord.): Enseñanza y educación en el País Vasco contemporáneo, Donostia, Erein, 2003, pp. 44-45. 
escolar de esas características, no podemos situar el análisis de ese fenómeno en un escenario puramente educativo. El País Vasco conocerá transformaciones -también Europa y el Estado español- que tendrán efectos de todo orden en la vida de los ciudadanos, incluida la enseñanza; cambios de tipo económico, social, político, ideológico y cultural que generarán las condiciones que harán posible el surgimiento de un movimiento sin precedentes en el contexto vasco y que cobrará unas dimensiones hasta el momento desconocidas: las ikastolas asumirán una presencia protagonista incontestable en el escenario escolar y cotidiano del País Vasco ${ }^{18}$.

En Gipuzkoa -junto con Bizkaia- ${ }^{19}$ el surgimiento y posterior desarrollo de ikastolas en el franquismo alcanza, en un periodo de tiempo breve, unas dimensiones colosales, atendiendo al propio contexto en el que surgen -el régimen dictatorial- y al tipo de agentes promotores que los dinamizan. Son justamente estos últimos los que trataremos de identificar so pena de reducir el fenómeno que estudiamos a una asombrosa explosión de iniciativa privada orientada a dar respuesta en el ámbito educativo y escolar a las necesidades que la sociedad - guipuzcoana en este caso- tenía respecto al euskera y a la cultura vasca, desterradas del sistema educativo. Prácticamente en apenas veinte años (a partir de la aprobación en 1979 del Estatuto de Autonomía de Gernika las posibilidades que en ese sentido se abren son otras), se conforma una red de ikastolas cuya sombra se despliega a lo largo de todo el territorio guipuzcoano. Salvo las contadas excepciones de las etxe-eskola ${ }^{20}$-y cuyo alcance es muy limitado tanto territorialmente como en número de alumnos-, los primeros años de la década de los sesenta alumbrarán una situación en la que al surgimiento de las primeras ikastolas localizadas de forma dispersa seguirán la creación de centros escolares de este tipo en todas las comarcas guipuzcoanas y prácticamente en el cien por cien de los municipios de este territorio, con la única excepción de núcleos con una población muy reducida.

\section{I. Evolución y distribución geográfica de las ikastolas}

En la primera mitad de los años sesenta se crearán ikastolas en unas diez localidades -el número de municipios de Gipuzkoa asciende a 88-, si bien, atendiendo al número de habitantes, ciertamente significativas. La propia capital -San Sebastián-, con tres ikastolas, se verá acompañada, entre otros, por municipios como Irun, Rentería, Andoain, Elgoibar y Eibar, núcleos de población cuya densidad resulta altamente significativa, muy superior a la media de la provincia.

18 Fernández, I.: Oroimenaren hitza. Ikastolen historia 1960-1975, Bilbo, Udako Euskal Unibertsitatea, 1994 .

19 ArríEn, G.: Las ikastolas de Bizkaia, 1957-1972, Donostia, Eusko Ikaskuntza, 1993.

20 Algunas etxe-eskolak evolucionarán hacia el modelo de ikastola que se conformará a lo largo de las décadas de los sesenta y setenta, mientras otras directamente desaparecerán. 


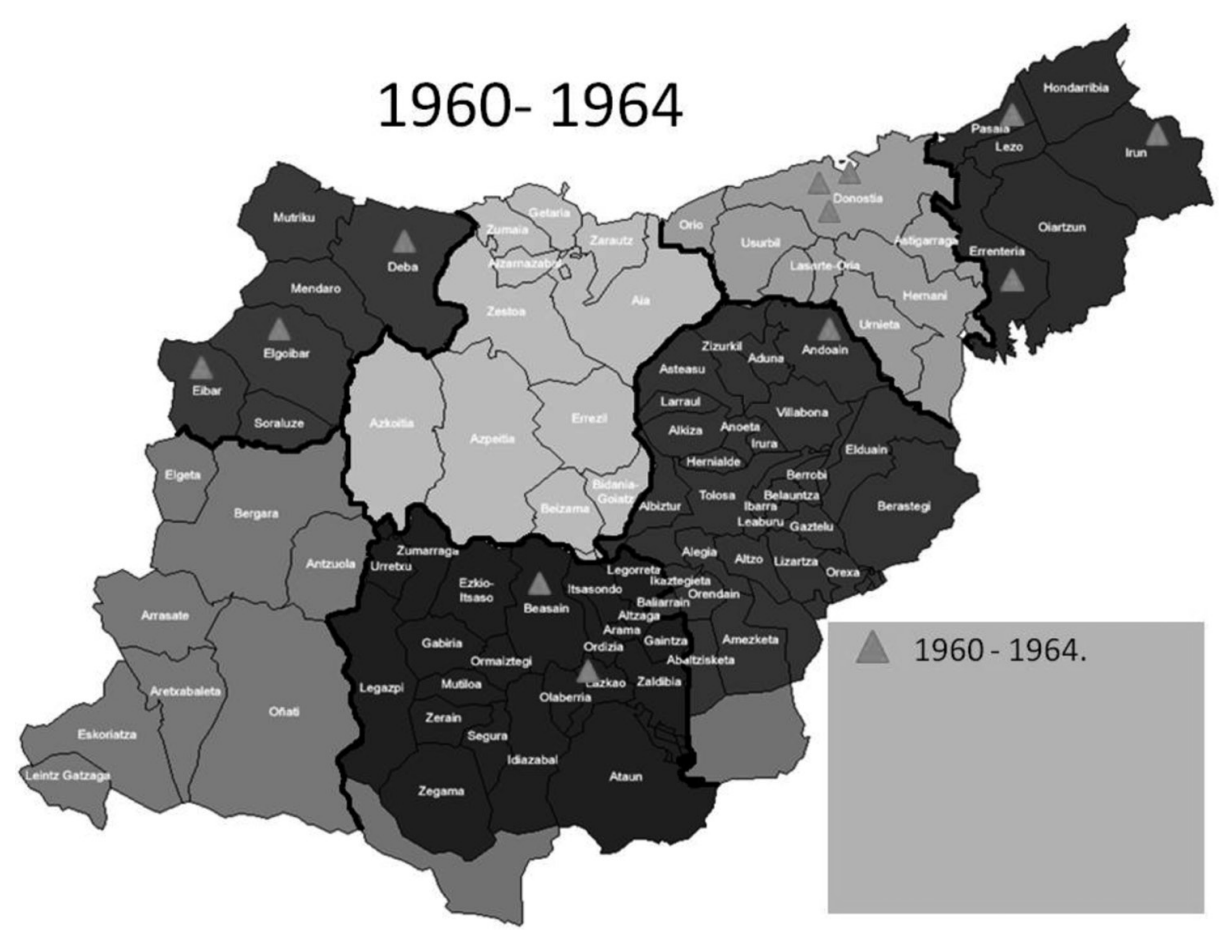

En el marco de un crecimiento de la población guipuzcoana de dimensiones extraordinarias ${ }^{21}$, constatar un reparto desigual del mismo resulta imprescindible para poder estimar con un grado de precisión mayor el alcance de la nueva situación: la tasa anual de crecimiento de la mayor parte de los municipios mencionados -en torno al $5 \%$ - supera claramente a la del territorio guipuzcoano en su conjunto $(3,4 \mathrm{I})^{22}$. No obstante, desde el punto de vista de la configuración comarcal de la provincia -muy relevante a los efectos de entender la realidad social y cultural de Gipuzkoa-, no puede sino señalarse cierto desequilibrio, en tanto hay algunas, como en el caso de Oarso-Bidasoa o del Bajo-Deva, en las que las mitad de sus municipios cuenta con ikastolas, mientras en otras no hay siquiera una sola (Alto-Deva o Urola-Costa).

No obstante, el efecto multiplicador -de proporciones notabilísimas- que tendrá lugar entre 1965 y 1969 posiblemente sirva para situar en sus correctas coordenadas el proceso de creación y desarrollo de las ikastolas en Gipuzkoa. El número de

${ }_{21}$ Ya en la década de los cincuenta era del 27,88\% frente al 8,7\% del Estado español, crecimiento cuyo ritmo se verá superado entre 1960 y 1965 , y que hay que situar en el desarrollo industrial, principalmente, y del sector de servicios que conocerá Gipuzkoa (Aguirre, J. A.: Así está la enseñanza primaria. Hablan los maestros. Informe Gaur, pp. 270-27I).

${ }_{22}$ En algún caso, Eibar por ejemplo, es en la década anterior cuando los porcentajes de crecimiento respecto a la media provincial se llegan a triplicar -situación similar a la que conocerá Zumárraga-. 
ikastolas aumentará enormemente en la segunda parte de la década cubriendo una amplia zona del territorio. La cantidad de ikastolas se quintuplicará, siendo las que se crearán en este periodo más del $80 \%$ del conjunto de centros creados a lo largo de esta década. El número de municipios que contarán con al menos una ikastola es superior al $65 \%$ (compartida en algún caso -Zumárraga y Urretxu, por ejemplo-; hay también quien cuenta con varias -significativamente el caso de San Sebastián). Salvo localidades como Bergara o Azkoitia, prácticamente todos los municipios urbanos contarán con la presencia de ikastolas; en general, las localidades que no tienen ikastola son de carácter rural o menores de 2000 habitantes. Desde la perspectiva de la distribución territorial no hay comarca que no cuente con un número significativo de ikastolas, dándose la circunstancia significativa de que en la inmensa mayoría de ellas el porcentaje de municipios en los que se localiza alguna es superior al 50\% (si no consideráramos la comarca de Tolosa-donde es destacable la presencia de muchas localidades rurales- ese porcentaje superaría el $70 \%$ ).

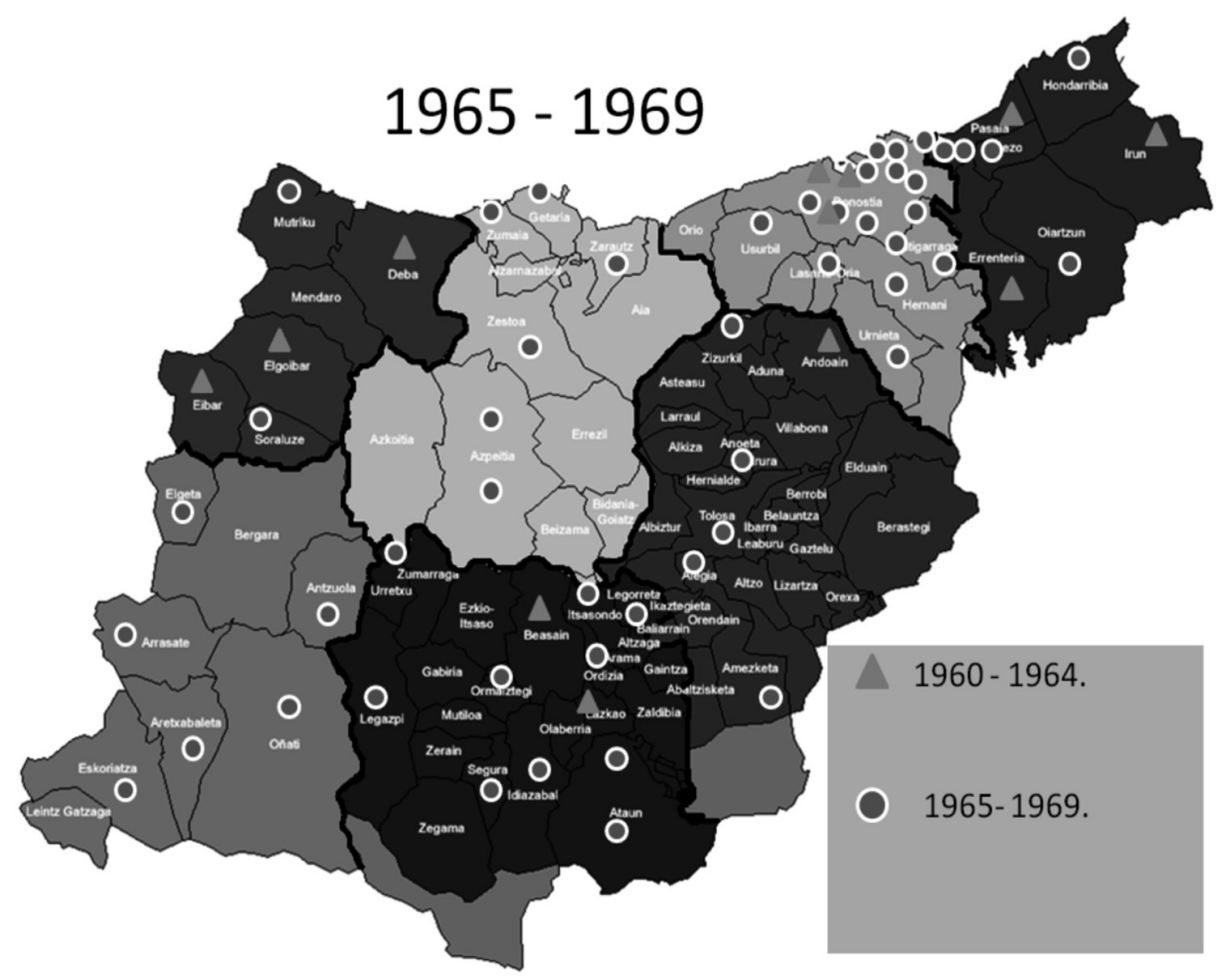

Esta situación no constituye un hecho fugaz, como vendrá a demostrar lo sucedido en la década de los setenta, periodo de tiempo que podríamos calificar como de estabilización en el proceso de creación y desarrollo de las ikastolas. Esto es, no se trata de un acontecimiento casual ni la resolución coyuntural a un déficit que presentara la escuela del momento: llegaron para quedarse y postularse como modelo escolar alternativo. 

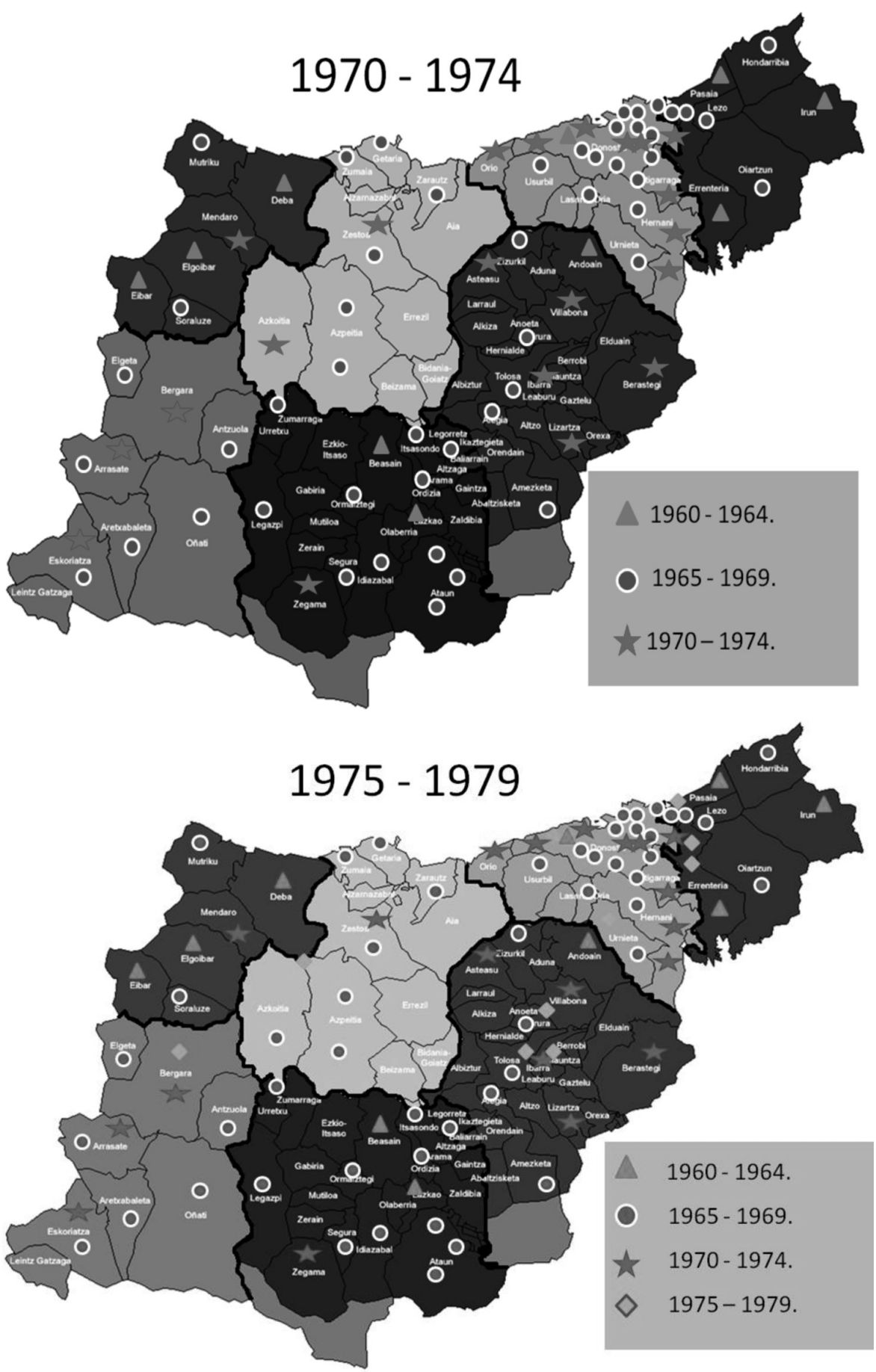


\subsection{Agentes promotores: al servicio del euskera y de la cultura vasca}

A la luz de lo expuesto surge la necesidad de encontrar respuesta a la cuestión básica de cuáles han sido los agentes promotores que expliquen la irrupción en el territorio de la escuela en Gipuzkoa de un modelo educativo, el de las ikastolas, que dé cabida a la lengua y cultura vascas, y lo haga, por otro lado, de forma tan contundente, tal y como ha quedado de manifiesto. Ante la evidencia de que no es el Estado -ni qué decir, las instituciones vascas a falta de un ordenamiento jurídico-político que lo posibilitase- quien promueve la creación de ikastolas, rendirse a la mera reducción de caracterizar a dichos agentes como privados resultaría realmente decepcionante. Efectivamente, si hubiéramos de encorsetar la percepción de lo sucedido a la cuestión de la titularidad de ese tipo de escuela nos veríamos obligados a limitar el estudio de este fenómeno a la tradicional diferenciación entre escuela pública y escuela privada, diferenciación que, entendemos, no constituye una herramienta útil de análisis, más allá de constatar que es la ley quien define qué es privado y qué es público. En ese sentido, identificar a los agentes promotores de las ikastolas constituye una vía pertinente para no caer rendidos ante el abrazo de lo obvio y, en consecuencia, limitar la posibilidad -si no abortarla- de entender este fenómeno.

De la documentación del Archivo General del Estado de Alcalá de Henares referente a las solicitudes cursadas al objeto de obtener la autorización pertinente para la creación de estas escuelas ${ }^{23}$, se puede identificar claramente a aquellas personas que cursan las mismas ${ }^{24}$. La normativa legal establece que sean sujetos particulares ${ }^{25}$ quienes soliciten la autorización correspondiente para el funcionamiento legal de las ikastolas, muchas de la cuales venían funcionando anteriormente de forma clandestina, constando en la mayoría de los expedientes como

${ }^{23}$ Archivo General del Estado, Exp. n. ${ }^{\circ}$ 7853: Urko-Parroquial Juan Antonio Moguel (Eibar); exp. n. ${ }^{\circ}$ 15.298: Juan Antonio Moguel (Eibar); exp. n. ${ }^{\circ}$ I0928: Nuestra Señora de Iciar (Deva); exp. 9294: Ntra. Sra. de Iciar (Deva); exp. n. ${ }^{\circ}$ 2350: San Francisco Javier (Mondragón); expedientes n. ${ }^{\circ} 3808$ y 4439: Agrupación Escolar Aranzadi (Vergara); exp. n. ${ }^{\circ}$ I0976: Egape (Urnieta); exp. n. ${ }^{\circ}$ I4818: José Miguel de Barandiarán (San Sebastián); exp. n. ${ }^{\circ}$ 9444: Urumea (Hernani); exp. n. ${ }^{\circ}$ II888: Parroquiales Aurtzaro (Oyarzun); exp. n. ${ }^{\circ}$ I5389: Herri Ametsa (San Sebastián); exp. n. ${ }^{\circ}$ I20I7: San Benito (Lazcano); exp. n. ${ }^{\circ}$ I08ı2: Ntra. Sra. de Loinaz (Beasain); exp. n. ${ }^{\circ}$ 9525: Santa Cruz (Legazpia); exp. n. ${ }^{\circ}$ II345: San Miguel Arcángel (Legorreta); exp. n. ${ }^{\circ}$ 9935: Lascurain (Tolosa); exp. n. ${ }^{\circ}$ II283: Ikastola (Azcoitia). Los expedientes localizados en el AGA no alcanzan a dar la medida de las ikastolas que se crearon en el periodo estudiado y, además de completar y contrastar la información que de ellos se puede obtener con otras fuentes (testimonios directos de los protagonistas, prensa del periodo, etc.), hemos tenido ocasión de analizar las historias que la mayor parte de las ikastolas guipuzcoanas publicaron con motivo de su aniversario.

${ }_{24}$ No faltarán casos cuando menos curiosos como es el del alcalde y jefe local del Movimiento de Azkoitia que en 1969 solicita autorización para el centro docente denominado «Escuela Ikastola» (la única que sepamos que en esta época recibe tal denominación). O el caso de la ikatola Urumea de Hernani en el que el presidente de Enseñanzas Urumea s.A., entidad promotora, recibe por parte de la Guardia Civil la calificación de «amante del Régimen», soldado «con las Tropas Nacionales hasta alcanzar la graduación de Capitán y que continuó en el servicio activo en el Ejército terminada la Campaña, hasta alcanzar la graduación de Comandante».

${ }_{25}$ Tanto el solicitante como cualesquiera otras personas (director/a, maestras/os) serán objeto de control (también político-policial) en relación a su conducta pública, privada y profesional. 
propietario del centro. De ello, en cualquier caso, aun cuando formen parte de la Sección de Enseñanza Primaria no Estatal del Ministerio de Educación y Ciencia, no necesariamente ha de llegarse a la conclusión de que la creación de los mismos obedezca a la iniciativa privada. Un análisis pormenorizado de los expedientes a los que hacemos referencia y la evolución de esas ikastolas nos llevan a constatar que la presencia de miembros de la Iglesia -en su mayor parte sacerdotes pertenecientes a parroquias donde se localizan dichas ikastolas- es abrumadora (de ahí la significativa presencia de ikastolas «parroquiales»). No obstante, de ello no puede derivarse la conclusión de que la Iglesia sea agente promotor de este tipo de iniciativa escolar ${ }^{26}$, sino más bien que brinda (a iniciativa de sacerdotes, no tanto de la institución) una tutela jurídica a centros escolares obligados a entrar en los cauces legales; de facto, la existencia de muchas de las ikastolas es anterior al carácter parroquial que legalmente tendrán ${ }^{27}$. Más bien habría de precisarse que «no fue la Iglesia en busca de las ikastolas, sino que éstas fueron en busca de aquella $»^{28}$ en un momento que bien podríamos definir como de emergencia: principalmente en 1968/69 cuando se decreta el estado de excepción en Gipuzkoa y el gobernador civil ordena que las escuelas que funcionaban al margen de la ley entraran en los cauces legales.

Incluso en el caso de aquellos particulares, no ligados a la Iglesia, se constata que los que cursan las solicitudes de autorización no constituyen sino la representación de un colectivo, que es realmente quien promueve la creación y desarrollo de las ikastolas, independientemente de que puedan constituirse incluso como sociedad anónima o escuela privada a efectos legales. No hablamos pues de iniciativa privada, sino más bien de agentes que hay que ubicar dentro de la sociedad guipuzcoana que impulsan iniciativas de carácter marcadamente popular. Prueba de ello la constituyen especialmente aquellas ikastolas surgidas a impulso de asociaciones de padres -que incluían también a miembros que sin ser padres participaban del proyecto de creación de ikastolas- o sociedades de carácter cultural, por no mencionar aquellas otras que conocerán la cesión de titularidad por parte de las mencionadas ikastolas parroquiales a cooperativas de enseñanza. En definitiva, la cuestión relativa a la titularidad de las ikastolas, más que brindarnos el carácter presumiblemente privado de los agentes promotores de este modelo escolar, da la medida de la versatilidad de un movimiento social, capaz de enfrentar las limitaciones que impone el régimen para hacer efectivo el deseo de una enseñanza en euskara.

${ }_{26}$ Más bien se habría de hablar de capacidad adaptativa de las ikastolas; como señala Rodríguez, aun cuando haya ikastolas, como tendremos ocasión de comprobar con mayor detalle, ligadas a la Iglesia, desde un punto de vista organizativo la característica fundamental del movimiento de ikastolas es el de crear asociaciones y estructuras propias -Rodríguez, F.: Ikatolak eta Euskal eskolak, Donostia, Orain, 1996, p. 46-.

${ }_{27}$ LASA, J.: Euskal Erria eta ikastola. Una polémica en torno a la ikastola, Donostia, Itxaropena, 197I.

${ }_{28}$ Ibidem, p. I73. Habría que decir, también, que no es menos cierto que la Iglesia establecerá determinadas condiciones que brindan una pista interesante respecto a las características del contexto histórico del momento: formación cristiana de los alumnos de las ikastolas, carácter apolítico de las mismas y expresa prohibición de opciones partidarias, respeto a la legalidad vigente, etc. Aizpurua, I.: «Ikastolen historiarako ikusbide bat (1960-1972)», en Gure Ikastola, Jakin sorta 6, 1972, p. 27. 
No puede ignorarse, por otro lado, un elemento significativamente determinante a la hora de valorar en su justa medida el movimiento a favor de las ikastolas. Esto es, en el periodo histórico en el que nos situamos, la preocupación sobre la lengua adquiere tintes novedosos, explicables en claves políticas: el euskera, más allá de identificarse como elemento central de una comunidad lingüística, se contempla como eje vertebrador de una comunidad nacional y su defensa -en este caso, dentro del ámbito escolar- adquiere una dimensión de compromiso militante en tanto afirmación contra el régimen franquista. En términos generales, los agentes promotores de las ikastolas guipuzcoanas son fácilmente identificables como pertenecientes a sectores vasquistas-nacionalistas, entendido el nacionalismo no desde el prisma estrictamente partidario, sino dentro de lo que podríamos definir como nacionalismo sociológico ${ }^{29}$. Históricamente, el euskera ha sido para el nacionalismo vasco -ya desde sus orígenes- uno de los pilares fundamentales de la personalidad nacional vasca y la defensa de una escuela donde ésta ocupe un lugar central ha sido concebido como determinante para la supervivencia de la misma nación vasca ${ }^{30}$. Durante el franquismo, principalmente es el contexto familiar euskaldun (vascoparlante), el marco en el que tiene lugar la conservación y reproducción del discurso nacionalista en el que, como acabamos de señalar, el euskera es un elemento fundamental de la identidad nacional vasca; identidad nacional que, desde sus presupuestos ideológicos, es combatida desde la escuela franquista $a^{31}$. Efectivamente, a estos efectos, el final de la guerra, a diferencia de lo que ocurrirá en el exilio donde el espacio público no se pierde, provocó un repliegue de las prácticas educativas hacia el espacio doméstico y una actividad «compensatoria» con la proliferación de actividades culturales -en muchos casos de carácter folklórico- en el ámbito comunitario, no excesivamente articuladas quizás, pero sí cargadas de intencionalidad política en clave de resistencia, lo que permitirá la conformación de un terreno donde, abonado también por la idea de combatir el franquismo, florecerá un movimiento de carácter popular que gestará una escuela alternativa a la del régimen.

Se ha de considerar, además, que a lo largo de los años sesenta y setenta el asociacionismo constituye en Gipuzkoa, así como en el resto del País Vasco, uno de los rasgos característicos de su sociedad. En ese sentido, la actividad socializadora de carácter social, política y nacional adquiere una intensidad notable en

29 Nos atreveríamos a decir que en general las estructuras partidarias, los partidos políticos en definitiva, se encontrarán durante un largo periodo instaladas en la espera de la colaboración exterior -espera de resultados siempre frustrantes- para hacer frente al régimen franquista -en la confianza de que la presión internacional acabara con el mismo-y que son justamente -aunque participen del mismo pensamiento ideológico- los ciudadanos organizados de forma colectiva quienes asumen un protagonismo evidente en la lucha contra el franquismo. No obstante, como en al caso de algunos testimonios que hemos recabado, no faltará quien señale la presencia de algún partido político, si bien pensamos que ésta puede ser una lectura realizada a posteriori -a la vista de la significación política de algunos personajes relevantes o de la afiliación de algunos tras la muerte de Franco-y no tanto el relato de lo acontecido.

30 ZABALETA, I.: Euskal nazionalismoa eta hezkuntza (I895-1923), Leioa, UPV/EHU, I998.

31 Fernández, I.; Uribe-Etxebarria, A.; Basurko, F.; Martínez, B.; Erriondo, L.; ZabaLETA, I. y LARRAZABAL, L.: «La transmisión de contenidos nacionalistas en el contexto familiar (País Vasco I940-1970)", Historia de la Educación, n. ${ }^{\circ}$ I6 (1997), pp. 363-372. 
el marco de barrios y pueblos ${ }^{32}$; y es precisamente el asociacionismo una de las claves que explica la conformación de agentes, no ya privados, sino colectivos de los cuales dependerá la creación y desarrollo de las ikastolas ${ }^{33}$. A ello colaboró, también, posibilitando que la tensión con el régimen se compensara -en términos de poder- con una participación social amplia ${ }^{34}$, la redefinición ideológica respecto a la lengua y cultura vascas dentro del nacionalismo vasco ${ }^{35}$, en función de un contexto social caracterizado por transformaciones evidentes (económicas, demográficas, urbanísticas, escolares, etc.), que en el caso guipuzcoano tendrá unos efectos interesantes: a saber, el euskera será, no ya un pilar, sino el pilar de la identidad vasca; redefinición a partir de la cual la reivindicación de la lengua pasará a ser asumida por fuerzas políticas nacionalistas nuevas e incluso por fuerzas no nacionalistas, además de constituirse como elemento sustancial de integración social, especialmente a partir de la década de los setenta.

Puede hablarse de una nueva formulación ideológica de la cultura vasca en el que la necesidad de su modernización apuntala la importancia de la escolarización en euskera; como afirman Dávila y Eizagirre al referirse, entre otras cuestiones, al surgimiento de las ikastolas: «El discurso modernizador de la lengua, en un contexto social de organización clandestina intensa, tiene su repercusión en el ámbito educativo vasco» ${ }^{36}$. Estos mismos autores señalan en otro trabajo ${ }^{37}$ que las nuevas transformaciones de orden social y demográfico generados por el desarrollo industrial sitúan en una posición crítica a la cultura vasca, de forma que una situación amenazadora deviene en oportunidad de modernización en el que la ikastola jugará un papel primordial. Esto tendrá lugar en un contexto más amplio de lucha popular en el que habría de situarse también la defensa, en términos generales, de la cultura vasca como elemento de afirmación colectiva de la comunidad vasca frente al impulso de disolución del mismo por parte del franquismo, o más concretamente -y en relación directa con la lengua- el movimiento popular de alfabetización y euskaldunización de adultos ${ }^{38}$. Confluyen, pues, la apuesta por la recuperación de la lengua y la resistencia y lucha antifranquista, de modo que la participación en el movimiento a favor de las ikastolas es entendida también, y

32 Pérez Agote, A.: La reproducción del nacionalismo. El caso vasco, Madrid, Siglo xxi, 1984. Sobre la importancia del asociacionismo en la lucha antifranquista, incluso como elementos sustitutivos de los partidos políticos en no pocas ocasiones, también en la defensa de la lengua y cultura vascas ver GURRUCHAGA, A.: El código nacionalista vasco durante el franquismo, Barcelona, Anthropos, 1985 .

33 La afirmación de que asociaciones culturales, deportivas, recreativas, etc., brindaron un marco de militancia a favor del euskera y de las ikastolas es constante en muchos de los testimonios analizados.

34 FERnÁNDEZ, I.: 1995, op. cit., p. 186.

35 DÁvila, P.: «Euskal alfabetatzearen ereduaren eraiketarako osagaiak», Uztaro, n. ${ }^{\circ} 5$ (1993), pp. 156 y ss.

${ }_{36}$ Dávila, P. y Eizagirre, A.: «Leer y escribir en las escuelas de Euskal Herria, I860-1990», en DÁvila, P. (coord.): 1995, op. cit., p. 74.

37 Eizagirne, A. y DÁvila, P.: «Alfabetatzea Euskal Herrian: ikuspegi historikoa», Ele, n. ${ }^{\circ} 8$ (199I), p. 43.

${ }_{38}$ Zabaleta, I.: «Euskal alfabetatzea eta herri mugimendua autonomiaren atarian», en Bilbao, B.; Perez Urraza, K. y Perez Urraza, K. (eds.): Paulo Iztueta Euskal pentsamenduaren eraikitzaile, Leioa, UPV/EHU, 2007, pp. 30I-318. 
de forma fundamental -muy particularmente en Gipuzkoa, que deviene en motor de ese movimiento- como forma de lucha popular contra el régimen. En ese sentido, más allá de detectar toda un mosaico variopinto de agentes privados que hacen opción por la militancia a favor del euskera en un alarde de conjunción de iniciativas particulares, en Gipuzkoa, así como en el conjunto del País, se ha de remarcar el carácter popular del movimiento a favor de las ikastolas subrayándose la dimensión comunitaria y colectiva del mismo que junto a la construcción de una realidad escolar alternativa -y por esa misma razón- combate contra la dictadura franquista ${ }^{39}$.

\section{La apuesta pedagógica de las ikastolas}

En la línea que venimos manifestando, incluso dentro del profesorado (especialmente en sus inicios y sobre todo en el periodo de clandestinidad), más que desde un punto de vista estrictamente profesional, su actividad es percibida desde una dimensión militante de resistencia antifranquista. $Y$ es que el colectivo docente y la labor que desempeñará nos permite remarcar nuevamente el carácter popular de las ikastolas en el que hasta los educadores, colectivo que no puede ser reducido a la categoría de meros empleados, se muestran como agentes promotores de un modelo escolar diferente y alternativo a la escuela franquista y a las escuelas de la Iglesia. Ciertamente podemos incluirlos junto a los padres, dentro de la dimensión comunitaria a la que hemos venido refiriéndonos y en el que hay que reconocer a toda una variedad de elementos impulsores y dinamizadores, como agentes educativos sin cuyo protagonismo resulta imposible explicar un movimiento combativo también desde presupuestos pedagógicos.

La insatisfacción respecto a la escuela del momento atendiendo a su carácter pedagógico tradicional es también constante en los testimonios que hemos podido recabar, tanto de protagonistas del momento como en las revistas de carácter cultural que en las décadas de los sesenta y setenta cobrarán una importancia indiscutible en la revitalización del euskera y en la socialización de la idea de la lengua como eje central de la comunidad nacional vasca ${ }^{40}$. Publicaciones como Jakin, Anaitasuna o Zeruko Argia, por mencionar algunas de las revistas más referenciales de la época, están asociadas a un amplio movimiento de carácter cultural del que las ikastolas forman parte y a las que inyectan elementos de vigorización social y política, constituyendo un altavoz impagable también de las bondades pedagógicas que las caracterizarían. Resultaría extremadamente prolijo detallar las innumerables ocasiones en las que se ponen de manifiesto los principios rectores que orientan los planteamientos alternativos a la escuela del periodo -ya

39 Como señala, de manera muy gráfica, uno de nuestros testimonios: sed y fuente confluyen en un periodo de lucha; no quedaba, pues, sino beber. Hay quien habla de un periodo de transformación y esperanza donde se materializa la opción por el combate a favor del euskera y la cultura vasca.

$4^{\circ}$ Muchos de los testimonios que hemos recabado coinciden no ya en la insatisfacción respecto a la escuela del periodo -incluidas las escuelas de la Iglesia-, sino además en el desprestigio de la misma. 
sea, como señalábamos ahora mismo, la «escuela nacional» franquista, ya la que está en manos de la Iglesia-. En ese sentido, Laspiur ${ }^{4 \mathrm{r}}$-impulsor destacado del movimiento de ikastolas, especialmente en la comarca del Deba- nos brinda una síntesis de los ejes fundamentales sobre los que gira el discurso crítico del movimiento de las ikastolas, a la vez que apuntala las bases sobre las que se asienta su apuesta pedagógica: defensa de los derechos humanos, principio de democracia y derecho de las personas y los pueblos.

La Conferencia General de la onu para la Educación, la Ciencia y la Cultura, atendiendo a la violación de derechos contemplados en la Declaración Universal de Derechos Humanos, aprobó en 1960 La Convención relativa a la Lucha contra las Discriminaciones en la Esfera de la Enseñanza, en la que se establece que los Estados Partes han de reconocer «a los miembros de las minorías nacionales el derecho a ejercer las actividades docentes que les sean propias, entre ellas la de establecer y mantener Escuelas y ...emplear y enseñar su propio Idioma» (art. 5.-I.c). Ni qué decir tiene cuán lejos estaba el Estado español de reconocer al País Vasco como minoría nacional ni al euskera como lengua de dicha minoría nacional cuando se aprobó y entro en vigor la Convención ${ }^{42}$, momento en el que no era Estado parte y, en consecuencia, no estaría obligado al mencionado reconocimiento; no será hasta 1969 que el Estado español depositó el Instrumento de Aceptación de la Convención, momento en el que, legalmente al menos, entró en vigor ${ }^{43}$. Ciertamente, la Declaración Universal de los Derechos Humanos no era legalmente vinculante, extremo éste sobre el que dio buena prueba el régimen franquista, aun cuando su ingreso en la ONU en 1955 -cabe pensar- pudiera obligarlo por la propia adhesión a los principios de la organización en la que ingresó (no puede obviarse que la Declaración fue adoptada, ya en 1948, como un modelo/espejo de realización para todos los Estados miembros). Si el derecho de los niños a recibir una educación en su propia lengua, en la lengua de su pueblo, resulta un argumento esgrimido una y otra vez en defensa de un modelo de escuela diferente, la ikastola, el derecho de los padres a decidir la educación de sus hijos e hijas cobra una fuerza enorme. No se trata de la simple elección de tipo de centro al que los padres pudieran enviar a sus hijos e hijas sino, repetimos, de decidir qué educación debieran recibir -de ahí que los padres, como sujeto colectivo, se constituyan en agentes promotores del movimiento de ikastolas- lo cual supone situarse frente al Estado o cualquier otra institución -la Iglesia- que pueda cuestionar ese principio fundamental.

A lo dicho hasta ahora se habrían de añadir otros principios -si se prefiere, más específicamente educativos- que marcan la reacción de las ikastolas también en el territorio de las alternativas pedagógicas a la escuela franquista. En primera instancia se sitúa la importancia suprema de los/as niños/as y la necesidad de que su formación se realice atendiendo a criterios científico y pedagógicos. En ese sentido cobra particular relevancia el que se atienda a su educación desde su especificidad, singularidad y necesidades, en definitiva, su personalidad. Por

41 Laspiur, I.: «Ikastola eta gurasoak», Gure Ikastola, Jakin sorta 6, 1972, pp. 55-90.

${ }_{42}$ Si bien se aprobó en 1960, no entró en vigor hasta 1962.

$43 B O E$, n. $^{\circ} 262$ de I de noviembre de 1969. 
otro lado, el modelo pedagógico de las ikastolas marcará la necesidad de una educación integral que respete el principio de libertad y autonomía del/la niño/a, situándolo/a en su contexto cultural y lingüístico, en un marco de trabajo cooperativo, remarcando la complementariedad entre padres y escuela, entendiendo ésta como escuela al servicio de la sociedad y el pueblo en la que se inserta.

Los planteamientos renovadores en ese sentido no son recientes y un acercamiento al pasado inmediato obliga a dirigir la mirada a las etxe-eskolak a las que ya nos hemos referido, y más concretamente a la figura de Elbira Zipitria, quien dentro de los planteamientos de la escuela nueva no sólo aplicará los principios de una pedagogía activa, sino que además iniciará y formará en los mismos a las primeras andereños de las ikastolas. Las iniciativas renovadoras desde un punto de vista pedagógico son anteriores a la dictadura franquista y Montessori, Decroly o Freinet forman parte del «santuario» pedagógico de experiencias educativas y escolares que conocieron su final con la victoria de los golpistas. No obstante, la figura de Elbira Zipitria traza un puente que conecta ese periodo con lo que luego será el movimiento de ikastolas que beberá directamente de fuentes ajenas a la pedagogía tradicional característica del periodo franquista ${ }^{44}$. Los agentes promotores de las ikastolas coinciden, en la línea que apuntábamos anteriormente, en que una de las razones que impulsaron su surgimiento fue la necesidad de una escuela diferente a la que conocieron y, añaden, padecieron, aunque muchos de ellos carecieran de un punto de vista pedagógico definido. En ese sentido, las etxe-eskolak de Donostia, a las que ya hemos hecho referencia, brindarán una experiencia donde la aplicación de principios teóricos renovadores cobrará una dimensión real en la que poder buscar elementos alentadores para la construcción de una escuela alternativa también desde el punto de vista pedagógico. En el corazón de la oscuridad pedagógica del franquismo experiencias renovadoras como las puestas en práctica en las etxe-eskolak donostiarras y los presupuestos teóricos que las sustentaban constituirán un punto de luz que, sobre todo a partir de la formación recibida de primera mano de Zipitria, alumbrará la senda por la que echarán a andar las primeras ikastolas.

La formación del profesorado, tal y como subraya Fernández 45 , constituyó en el periodo que hemos estudiado uno de los factores determinantes en el devenir del movimiento de las ikastolas y a las carencias que presentaba la titulación de magisterio con el objetivo de hacer frente al enorme reto que se planteaba se hubo de responder en claves militantes y de organización popular y autogestionaria ${ }^{46}$. En primera instancia, las etxe-eskolak constituyeron un laboratorio de prácticas para aquellas maestras -tituladas o no- que luego se harían cargo de las ikastolas para las que eran reclutadas por parte de los padres considerando-además de que

44 Fernández, I.: «La renovación pedagógica en el País Vasco», en Dávila, P. (coord.): 2003, op. cit., pp. $84-85$.

45 Ibidem, 88 .

${ }^{4} 6$ De hecho, en muchos casos el reclutamiento de profesorado se realiza, como subrayan diferentes testimonios, en el territorio de la militancia popular en favor del euskera. En otras situaciones la captación sigue otro camino: dirigirse a familias nacionalistas para animar a sus hijos/ as para que estudiasen magisterio, integrándolos/as en la red militante de carácter popular a la que nos referimos. 
dominaran el idioma- su afinidad con el proyecto en construcción. La inexistencia de centros de formación del profesorado que tuvieran como horizonte una escuela vasca, libre, progresista y que considerara al País en su conjunto desde claves nacionales -lo cual tendría efectos, además de una enseñanza de y en euskera, en el currículum (historia, geografía, cultura, literatura, etc.)- determinó la necesidad de crear, al margen de las Escuelas Normales del periodo, una Escuela que pudiera dar respuesta satisfactoria en ese sentido. Así, ya en el año 1964, surgió en la capital guipuzcoana la que se denominó Escuela de Educadores Joanes Etxeberri y que reunió a lo largo de una década a estudiantes de la Escuela Normal de Donostia. La que se conoció como Residencia de Andereños brindaba una formación complementaria en ámbitos -todos ellos, o no contemplados en los planes de formación de las Normales, o desde una perspectiva de renovación escolar, ajena a esas instituciones- como euskera, cultura vasca e, incluso, psicología, pedagogía y metodologías didácticas ${ }^{47}$.

Pero estas maestras no se limitan al ejercicio de la profesión en el marco de sus respectivas ikastolas. Setién ${ }^{48}$, quien junto a Santamaría y Zumalabe -figuras referenciales en la creación y desarrollo de las ikastolas guipuzcoanas-, impulsó el centro que bajo la dirección de Frantziska Arregi asumió la formación de las mismas, hace mención expresa a la configuración de un movimiento de enseñantes. El testimonio de quien fuera no sólo testigo sino actor protagonista del movimiento a favor de las ikastolas desde sus orígenes marca la relevancia del proceso de formación permanente que se genera a partir de un trabajo de carácter cooperativo que teje una red que facilita el intercambio de experiencias, la creación de materiales escolares y la organización de cursos de formación. La clave del proceso de construcción de la ikastola, también desde la perspectiva del profesorado, reside en la apuesta colectiva que hace de la confianza en el carácter transformador de la escuela, fundamento sustancial de una labor profesional y militante conscientemente asumida. Porque es justamente ese convencimiento en la posibilidad de transformar la realidad del País, aun cuando suponga necesariamente el hacer frente a unas condiciones no exentas de peligro incluso, lo que determina la elección de la ikastola como territorio de lucha -de activismo militante- y trabajo. En ese sentido, el profesorado se muestra totalmente consciente de estar enfrentándose al régimen cuando hace opción por un modelo de escuela que pivota por una parte alrededor de los ejes euskera/cultura vasca y, por otra, hace de los derechos individuales y colectivos principios motores de su actividad, sintiéndose/sabiéndose parte de un movimiento popular.

47 Allur, A.: «Ikastolak eta irakasleak», Gure Ikastola, op. cit., p. 49. Quien fue una de las primeras andereños guipuzcoanas -se inició, como tantas otras, sin haber estudiado magisterio-, afirma categóricamente que los estudios de magisterio ni estaban organizados ni pensados para dar respuesta a las necesidades formativas del País; de ahí la necesidad de capacitación a través de vías alternativas como la de la Residencia.

${ }_{48}$ SETiÉN, J.: «Gordailu eta Euskal pedagogia», Jakin, II (I979), p. Io6. Setién fue una figura clave, tanto a la hora de buscar maestras para las ikastolas como para crear materiales didácticos para las mismas, además de creador de Gordailu -asociación a la que luego habremos de referirnos- para dar respuesta a las necesidades de formación continua del profesorado. 
Será de ese movimiento popular del que formará parte sustancial el movimiento de enseñantes de las ikastolas quien, tal como señalábamos ahora mismo -sin limitarse a la formación de la Residencia-49, teje una red de colaboración que, partiendo desde la ikastola/pueblo, se organiza en valles/comarcas hasta alcanzar el territorio guipuzcoano para proyectarse, posteriormente, a nivel nacional. En cualquier caso este tejido organizativo no se limita a la coordinación interna, sino que se proyecta al exterior contactando y estrechando relaciones con sectores de Movimientos de Renovación Pedagógica, particularmente con la asociación catalana Rosa Sensat. Tal y como afirma López-Goñi ${ }^{\circ}$, el proyecto educativo de las ikastolas estuvo, desde sus mismos orígenes, impregnado de un espíritu innovador que hizo que su apuesta pedagógica trascendiera el marco escolar para configurarse como agente de transformación social, a su vez abierto a la participación social poniendo en evidencia, también, la dimensión educadora de la sociedad. El movimiento de enseñantes de las ikastolas se dotó, además de elementos organizativos a los que nos referiremos, de instrumentos que respondieran a las necesidades de experimentación y teorización inherentes a su apuesta por una formación permanente, tales como los cursos de verano o las ikastaldia (periodo de formación), que se celebrarán anualmente; una revista que -además de aportaciones teóricas solicitadas expresamente-facilita un contacto permanente entre experiencias de un lado y otro estableciéndose un nexo de unión entre el profesorado de las ikastolas, o la misma Haurride, tienda situada en Donostia que oferta, entre otras cosas, juegos educativos y materiales didácticos. Pero resulta difícil, si no imposible, explicar lo acontecido en este terreno sin considerar los elementos organizativos a los que hacíamos mención; en ese sentido, y situados en Gipuzkoa aunque con una proyección de carácter nacional, el surgimiento de la asociación Gordailu constituye, en el ámbito de la renovación pedagógica, un hito notablemente relevante en la historia de las ikastolas ${ }^{\mathrm{sI}}$.

Con sede en Donostia, se constituye, en el curso 1968/69, como asociación de profesores que aglutina ya en los inicios de la siguiente década a cientos de asociados y se dota de una estructura que cuenta con liberados también en el resto de territorios del sur del País. Tratará de dar respuesta a la necesidad de una organización más eficaz del trabajo cooperativo de los mismos y situará su campo de acción -con el fruto que líneas más arriba hemos querido poner en evidenciasobre tres pilares fundamentales: formación del profesorado, creación de material didáctico y trabajo editorial. Todo animado por un principio fundamental que, tal y como queda recogido en sus estatutos, no es otro que el de impulsar la libertad de los/as niños/as a través del desarrollo de una educación inserta en la realidad concreta del País Vasco ${ }^{52}$. Esta realidad, con toda seguridad, constituyó una poderosa razón para que Gordailu conociera de cerca aquellos rasgos que,

49 A inicios de los años setenta la mayor parte del profesorado de las ikastolas había sido formado en la Residencia (Escuela Joanes Etxeberri).

so López-GoÑI, I.: «Las ikastolas en Navarra (siglo xx): búsqueda de un modelo de escuela propio", Historia de la Educación, 24 (2005), pp. 389-391.

ऽı DÁvila, P.: «La renovación pedagógica en el País Vasco. Segunda mitad del siglo xx», Sarmiento, 9 (2005), pp. 92-93.

52 Gordailu Arduradun Taldea: «Gordailu», Urrats, Euskal pedagogia aldizkaria, o (1978). 
entre otros, caracterizaron al régimen franquista: dificultades para organizar cursos o publicar libros en una constante lucha por evitar los envites de la censura o persecución policial directa con registros de su sedes ${ }^{\text {s }}$.

En el marco ya de los nuevos modos de organización de que se dota el movimiento de ikastolas, idea central sobre la que girará nuestro trabajo a continuación, y dentro del ámbito del profesorado, los últimos años de la década de los sesenta conocerán el nacimiento de Gipuzkoako Ikastoletako Irakasleen Elkartea (Asociación de Profesores de las Ikastolas de Gipuzkoa), antecedente de la asociación que a partir de 1972 aglutinará al profesorado de todas las ikastolas del País (Ikastoletako Irakasleen Elkartea). Además de cuestiones relativas al ámbito pedagógico y de formación del profesorado -nunca, en cualquier caso, en la medida de Gordailu-, esta asociación se adentra en un territorio que podríamos calificar de carácter sindical, en el que la defensa de los derechos de los maestros y maestras se realiza desde la perspectiva de trabajadores/as de la enseñanza -en cierta medida, asumiendo su posición también en términos de clase-, ámbito laboral que no abandonará hasta la década de los ochenta donde este frente de acción es asumido por los sindicatos en un contexto histórico bien diferente al de la dictadura franquista.

\section{Los modos de organización de las ikastolas}

Resulta difícil, si no imposible, explicar y entender el surgimiento y posterior evolución de las ikastolas en Gipuzkoa -también en el resto de territorios del País- sin atender a uno de los rasgos más característicos de su sociedad; a saber, la identidad comunitaria, la conciencia de formar parte de una misma comunidad, que posibilita -además de lazos de solidaridad evidentes- $-^{54}$ tejer una red de relaciones donde la comunicación y el trabajo cooperativo constituyen sus más firmes pilares. Son precisamente esas claves las que permiten ubicar en sus justas coordenadas el hecho de que las ikastolas cuenten con parecidos modos de organización atendiendo al tipo de administración interna de la que se dotan, mantengan una relación permanente entre ellas, establezcan nexos de comunicación con agentes sociales y culturales del entorno y, finalmente, se doten de una estructura común para el conjunto de las ikastolas, en el caso que nos ocupa, la Federación de Ikastolas de Gipuzkoa (Gipuzkoako Ikastolen Elkarte Batza).

Los orígenes de las ikastolas guipuzcoanas desde un punto de vista organizativo no podía ser más básico y los primeros pasos dados responden a un esquema muy elemental: a partir de una idea motor -necesidad de que el euskera gane el espacio escolar como una de las condiciones fundamentales para su supervivencia-,

53 Setien, J.: 1979, op. cit., p. I07.

${ }_{54}$ Con toda seguridad, en el ámbito de la solidaridad económica la organización de Kilometroak contituye la fórmula de cooperación popular -también desde el punto de vista organizativo- más conocida que ha permitido recaudar fondos para las ikastolas en Gipuzkoa desde los años setenta. En el resto de territorios vascos la fórmula adquiere para los mismos una denominación específica (Ibilaladia en Bizkaia, Nafarroa Oinez en Navarra, Araba Euskaraz en Alava o Herri Urrats en el País Vasco Continental). 
idea que se comunica en un marco de relaciones caracterizadas por su cercanía (familia y amigos en primera instancia, localidad después), los primeros esfuerzos se orientan a, sustancialmente, captar alumnos/as, buscar maestras y disponer de espacios (locales) aptos donde poder ubicar las ikastolas que se quieren poner en funcionamiento, además de, claro está, buscar las vías de financiación que la situación demandaba. Obviamente, el contexto político no favorece movimientos espectaculares en ese sentido y son modos de operar clandestinos -o semiclandestinos-ss los que definirán el periodo inicial en el que va tomando cuerpo el movimiento a favor de las ikastolas. No es el caso de todas las ikastolas; incluso algunas -sería el caso del Liceo Santo Tomás en Donostia-fueron legales desde un primer momento (a ello contribuiría el que Carlos Santamaría -junto a Mitxelena y Zumalabe, promotor principal de este centro- hubiera sido preceptor de Juan Carlos de Borbón) o recurren a personas que por su vinculación a alguno de los aparatos del Estado no resultarían sospechosos de incurrir en actos subversivos (caso de la ikastola Urumea de Hernani) ${ }^{56}$. En cualquier caso, si bien no podemos afirmar que exista un patrón absolutamente común a todas ellas, un modelo totalmente homogéneo de funcionamiento -sea en el terreno de la legalidad o la alegalidad-, el núcleo organizativo básico de todas las ikastolas lo constituye la Junta de Padres ${ }^{57}$-Gurasoen Ikastola-Batzordea- que a partir de aquellos primeros grupos que en sus orígenes aglutinaban a un reducido número de miembros pasarán a representar al conjunto de padres y es la instancia responsable de todas las cuestiones de índole organizativa de cada centro escolar: profesorado, espacio y financiación, básicamente.

Pero las pautas de funcionamiento no pueden reducirse a una dimensión local, ni siquiera la superación de esta dimensión local puede ser entendida como posterior paso en la secuencia de desarrollo y evolución de las ikastolas; éstas no brotan espontáneamente y se constata un nivel organizativo relativamente informal -esto es, no estructuralmente configurado- que supera el marco ikastola/ municipio y que en muchos casos incluso explica su origen. El testimonio que en ese sentido brinda Paulo Agirre -testigo directo desde los orígenes mismos de las ikastolas- resulta muy ilustrativo; el movimiento a favor de las ikastolas se explicaría desde el vínculo que éste tiene con otros movimientos sociales y culturales que teniendo su expresión en el marco local lo trascienden por extenderse a lo largo de todo el territorio, incluso el País. No se trataría, pues, de un movimiento paralelo ajeno al contexto general donde cobra entidad y significación;

"Al parecer, prácticamente todo el mundo en los pueblos -concretamente en los sectores vasquistas y nacionalistas, mayoritarios en Gipuzkoa- era conocedor de los pasos que se estaban dando con el objetivo de crear ikastolas; la, en general, discreción y prudencia con la que se dieron explicaría que las autoridades, no ya locales -en no pocos casos «cómplices», muy próximos a los sectores que mencionábamos-, sino las directamente afines o pertenecientes al régimen, mostraran cierto «desentendimiento». En cualquier caso, no puede ignorarse que, tal y como refieren muchos testimonios, se asumen riesgos frente a los que no caben lecturas frívolas (peligro, miedo, ocultamiento, cautela, vigilancia, persecución, amenaza, etc., son expresiones que se repiten continuamente).

${ }_{56}$ Ver nota n. ${ }^{\circ} 24$.

57 Cuando decimos «padres» hacemos referencia tanto a padres como a madres; en euskera el concepto gurasoak integra a ambos. 
es más, aunque pudiera parecer que los padres fueron los agentes promotores de las ikastolas, no hubieran alcanzado su propósito sin el concurso y la ayuda de dichos movimientos, tanto en lo que se refiere al impulso popular inmediato en defensa del euskera y de un proyecto fundamental para su supervivencia, como al escenario de contactos y relaciones que brindaban y que posibilitaron, en definitiva, un marco de comunicación, actividad y colaboración constatablemente fructífero. Ésa es la clave que permite entender que el fenómeno de las ikastolas se constituya en símbolo de vasquidad y de productor de identidad colectiva, un lugar donde confluyen tanto el movimiento cultural como el político, un referente de denuncia y de reivindicación de y en los últimos años del franquismo, en definitiva un territorio de resistencia antifranquista ${ }^{88}$. Tal y como señala Arpals9, la ikastola cuestiona el sistema educativo franquista en tanto aparato del Estado (especialmente en su dimensión ideológica de legitimación del régimen) y brinda una alternativa educativa y escolar al objetivo de recuperación de la lengua y la ansiada normalización del euskera ${ }^{60}$. Por eso mismo la apuesta por el movimiento a favor de las ikastolas aglutina en su entorno a amplios sectores populares, de manera muy significada en Gipuzkoa, facilitando -si no directamente animándolo- el encuentro y la colaboración indispensables para que el proyecto cobrara un impulso definitivo.

Sin que la uniformidad o la homogeneidad caracterizara al movimiento de ikastolas, incluso cuando no se viera libre de disensiones y conflictos ideológicos que derivaron en situaciones realmente críticas ${ }^{61}$, supo dar muestras de una capacidad evidente para enfrentar las dificultades que ponían en riesgo su proyecto, cuestión que no puede explicarse si no es desde claves organizativas de carácter colectivo. Si ya en los primeros años de los sesenta el surgimiento de las ikastolas se explica desde un punto de vista organizativo también por las redes sociales a las que ya hemos hecho mención y por asumir una estructura básica común que descansa en las Juntas de Padres que se comunican y colaboran entre ellas -ya no hablamos de algo parecido a unas academias particulares, las etxe-eskolak o escuelas domésticas-, la necesidad de captar y formar profesorado -además de las cuestiones ya expuestas con anterioridad-o atraer colaboradores y buscar fuentes

${ }_{58}$ El análisis que anteriormente hemos realizado en torno al profesorado de las ikastolas es perfectamente válido también al referirnos al colectivo de padres y, en general, a los sectores populares que lucharon a favor de las mismas.

59 Arpal, J.: «Educación y sociedad (1936-1984)», en Euskal Herria (1936-1984). Errealitate eta Egitasmo. Realidad y Proyecto, Jakin /Caja Laboral, I985, p. 314.

60 Ante quienes han querido reducir el fenómeno de las ikastolas a un escenario que se reduce a lo que bien pudiera definirse como una revitalización de carácter estrictamente cultural, en clara referencia al despertar y fortalecimiento de la cultura vasca, Azurmendi sitúa el fenómeno en claves radicalmente políticas que tienen su reflejo en el terreno cultural: «Renacimiento cultural que responde al renacimiento nacional», fenómeno que, añade, no es específicamente vasco y que se extiende a las minorías oprimidas, también en Catalunya o Galicia (AzURMENDI, J.: «Euskaldunari», en TorrealdaI, J. M.: Euskal idazleak gaur. Historia social de la lengua y literatura vascas, Jakin, 1977).

${ }_{61}$ El problema religioso, la estandarización del euskera, el clima político o el supuesto -para algunos sectores- carácter burgués que tenían constituyeron los pilares fundamentales de los conflictos vividos en el seno de las ikastolas. Este tema ha sido estudiado en detalle en el trabajo de FERnÁNDEZ (1994), al que nos hemos referido en varias ocasiones. 
de financiación, incluso la necesidad de responder eficazmente a los imperativos de índole legal, tienen su campo de operaciones en un corpus de organización colectiva. En el seno de cada ikastola podemos hablar de una comunidad constituida por padres/madres, profesorado, estudiantes y colaboradores; los padres y los estudiantes no son clientes de las ikastolas, como los profesores no son meros trabajadores, son parte y miembros activos de la organización de las mismas y junto a la participación de agentes sociales en cada una de ellas conforman unos modos organizativos que permiten hablar de la existencia de una comunidad que los hace posibles. Pero necesariamente se ha de considerar una comunidad más amplia que trabaja y se organiza colectivamente; esto es, la colaboración puede percibirse tanto como necesidad cuanto como modo de operar que da respuesta a la misma -difícilmente explicable sin la existencia de una identidad comunitaria, nacional incluso-, de modo que el trabajo cooperativo que se despliega tiene efectos de tipo organizativo ${ }^{62}$. En ese sentido, si bien los primeros años no están exentos de buenas dosis de improvisación urgidas por la necesidad, se crean rápidamente pautas y marcos de organización que se demuestran eficaces.

Ya en los primero años de la década de los sesenta -si bien, como señala Fernández ${ }^{63}$, surgen sin una planificación previa y se organizan autónomamente- las ikastolas existentes organizan, impulsadas por su necesidad de expansión, unas pautas de funcionamiento coordinado en las que fundamentalmente cabe destacar la transmisión de información, compartir experiencias y modos de enfrentar las dificultades y dar respuesta a las necesidades que surgían y, en definitiva, colaborar en el éxito de cada uno de los proyectos. Las ikastolas, abandonando las situaciones de clandestinidad/semiclandestinidad o alegalidad, compartirán unas orientaciones estratégicas con el objetivo de alcanzar una situación legal. En el 1965 la obligatoriedad de que cada estudiante tuviera su Cartilla de Escolaridad generó no pocos quebraderos de cabeza -ya fuera por efectivamente cumplir la ley, lo cual se tradujo que no pocas de las ikastolas funcionaran como escuelas parroquiales o que contaran con la complicidad de profesorado de las escuelas públicas ${ }^{64}$, o porque se suscitaron dudas y miedos en torno al propio proyecto- y la provisionalidad de las soluciones que se planteaban hicieron que el de la legalización de las ikastolas existentes y el de la creación de ikastolas nuevas ya con todas las bendiciones de la ley sea un propósito que compartirán ${ }^{65}$. Pero, como queda dicho más arriba, además

${ }_{62}$ Este análisis, en lo que hace referencia a la conciencia de pertenecer a una comunidad nacional, puede resultar válido también para Bizkaia, pero el caso de las ikastolas de los otros territorios vascos quizás requiera mayor prudencia toda vez que el nacionalismo vasco no tiene tanta fuerza como en estos dos y sea, como hemos venido planteando -refiriéndonos a su dimensión sociológica, no tanto partidaria- una de las razones de su desarrollo. En cualquier caso, el trabajo cooperativo tiene hondas raíces en la sociedad y cultura vascas y entre sus miembros es conocido como auzolan, que podríamos traducir como trabajo comunal, como tarea que entre vecinos se desarrolla en común.

${ }_{3}$ FERnÁndeZ, I.: 1995, op. cit., p. 179.

${ }^{6}$ No faltan, en sentido contrario, testimonios respecto al frente antiikastola que tenía como protagonistas a maestros/as nacionales.

${ }_{65}$ Como ya hemos señalado con anterioridad, el Liceo Santo Tomás de Donostia era legal desde su origen y son el resto de ikastolas guipuzcoanas existentes y las que se crearán en las segunda mitad de los sesenta -ni qué decir a lo largo de la siguiente década- las que habrán de tomar la senda de su legalización. 
de objetivos las ikastolas compartirán modos de organización que posibilitarán la coordinación entre ellas, coordinación que desde un punto de vista organizativo culminará a mediados de los sesenta en la creación de Ikastola Batzordea, la primera asociación de ikastolas y antecedente de las que luego serán las organizaciones de las que se dotará el movimiento de ikastolas -tanto federaciones de Ikastolas a nivel territorial como las nacionales-. Sus reuniones tenían lugar en Gipuzkoa (concretamente en los Pasionistas de Urretxu) aunque participaban representantes de ikastolas de todos los territorios vascos, incluida la zona continental del País ${ }^{66}$. Según refiere Agirre ${ }^{67}$, también actor protagonista en la asociación, fundamentalmente tomaban parte en las mismas tanto padres como colaboradores, aunque de forma esporádica contaran también con la participación de algunos profesores. Esta asociación, más que una organización estructurada, constituyó un órgano de colaboración y coordinación donde poder compartir experiencias de las que luego cada centro pudiera extraer alguna lección interesante, si bien también adoptó algunos acuerdos y desarrolló trabajos, principalmente en el ámbito de la captación de nuevo profesorado y en la organización de colonias escolares.

No obstante, Ikastola Batzordea desaparecerá a los pocos años -en el I968como consecuencia de la ruptura que conocerá en su seno, sea porque había ikastolas que apostaban decididamente por la legalización mientras otras preferían mantenerse discretamente a la sombra de la alegalidad, ya porque había diferencias en torno a la dirección que se quería imprimir al movimiento -todas ellas cuestiones de índole interna- o por efecto de razones externas, especialmente el estado de excepción decretado en Gipuzkoa junto el cierre ordenado de las ikastolas que estaban sin legalizar, lo que no hizo sino agudizar las diferencias que ya existían sobre la cuestión de la legalización. En un contexto de conflicto social y político cada vez mayor, también las ikastolas serán víctimas de la represión del régimen con, entre otras, las consecuencias de orden organizativo que marcarán el rumbo de los siguientes años. Así, tras la ruptura de Ikastola Batzordea, la mayor parte de las ikastolas guipuzcoanas buscarán el amparo de la Iglesia; las que eran partidarias de la legalización comenzaron a reunirse en Donostia para luego confluir en diversos encuentros en Tolosa con quienes aún habían optado por mantener las reuniones de Urretxu -queriendo dar en cierta manera continuidad a la asociación, aunque ya muy menguada- y finalmente terminar por constituir Gipuzkoako Ikastolen Elkarte Batza en I969; esto es, la Federación de Ikastolas de Gipuzkoa.

Esta Federación, primera surgida dentro del movimiento de ikastolas y precedente de la Confederación que aglutinará a las del País siguiendo su modelo ${ }^{68}$,

${ }_{66}$ Los representantes de las ikastolas de Bizkaia que tomaron parte en las reuniones de Urretxu crearon un grupo específico en Euba (Eubako Taldea) antecedente de lo que años después, concretamente en el 1977, sería la Federación de Ikastolas de Bizkaia, Bizkaiko Ikastolen Elkartea, esto es, ocho años más tarde que la de Gipuzkoa (UrRekoetxea, M.: «Bilbo euskalduntzen, ikastolen ikuspegia», en Bilbon Mundua ikusi, Bilbo, Mendebalde, 20Io, p. 93).

${ }_{67}$ IzA, I.: Ikastola mugimendua. Dabilen Herria. Ikastola eredua (I960-20Io), Bilbao, Euskaltzaindia. Euskal Herriko Ikastolak, 20Io, p. 57.

${ }_{68}$ Meses antes surgió Seaska, quien posteriormente aglutinaría a las ikastolas de la zona continental del País, pero en esos momentos no lo hizo como federación puesto que la ikastola de Baiona era la única del territorio. 
cuya necesidad se planteó en las reuniones de Donostia -si bien no pueden obviarse los antecedentes que tenían a Urretxu como centro de operaciones-, nace como instrumento de las ikastolas guipuzcoanas que entienden que el futuro pasa por dotarse de una estructura organizativa que brinde bases sólidas de funcionamiento en un momento que cabría calificar de emergencia. Son precisamente las dificultades a las que hemos hecho mención -estado de excepción, represión, cierre de ikastolas- las que determinarán que sea la Iglesia la institución bajo cuya protección busquen refugio en la confianza de que ésta se encuentra a salvo de las embestidas del régimen. La tutela jurídica que pretendió de la Iglesia determinó que se constituyera como «Federación Diocesana» ${ }^{6}$, fruto de un proceso no exento de dificultades y, también, confrontaciones ${ }^{70}$. La Iglesia asumiría la defensa de las ikastolas, pero a cambio, más allá de reducir su función a simples trámites administrativos -si bien no habrá quien deje de defender que ésa era un opción de los propios padres de familia-, habrían de asumir ciertos principios como condición inexcusable para ser asumidas como propias de la organización eclesiástica. En una asamblea celebrada en el Seminario de Donostia en junio del 1969 el delegado diocesano, nombrado a los efectos por el Obispado, establecerá como condiciones que las ikastolas tuvieran un carácter confesional, fueran legales, libres de ideologías políticas, los padres asumieran por completo la economía de los centros y la Iglesia fuera el responsable principal ante la ley ${ }^{71}$. Será unos meses más tarde, en noviembre, cuando se convoque la que la propia Federación reconoce que fue denominada como Ama Batzarra (Asamblea Madre) en Loiola, Azpeitia. En ella se constituirá la Federación de Ikastolas de Gipuzkoa y se aprobarán sus estatutos y estructuras, asumiendo funciones fundamentales para el conjunto de las ikastolas guipuzcoanas desde un punto de vista pedagógico, económico y legal ${ }^{72}$ (en este tiempo, 1968/69, y en estrecha relación con este acontecimiento, se produce la primera legalización masiva de ikastolas).

La Federación demostrará ser una herramienta de trabajo especialmente eficaz, dotando a las ikastolas de servicios y estructuras comunes y adoptando decisiones colectivas que se aplicarán en cada una de las mismas, sobre todo a partir

69 Si bien no será hasta 1975 cuando se oficializará el amparo jurídico de la Iglesia -tutela que se abandonará tres años más tarde dadas las nuevas perspectivas que se generaron tras la muerte de Franco y la apertura a un nuevo marco político-, nacerá bajo el cobijo de la misma y con la denominación en castellano de «Diocesana».

Algunos sectores llegaron a denunciar la pérdida del carácter popular de las ikastolas por asumir éstas el control que en adelante iba a ejercer la Iglesia; en ese sentido, el profesorado fue especialmente crítico y en años posteriores, bajo la calificación de rojos -gorriak- se produjeron incluso despidos en ikastolas como Andoain, Arrasate, Urretxu..., lo cual da la medida de las tensiones internas que conoció el movimiento -reflejo vivo de lo que acontecía en la sociedadcuando ya el régimen estaba a las puertas de su fin.

7 LASA, J.: I97I, op. cit., pp. I28-I3I. Las ikastolas fueron convocadas por el delegado diocesano en nombre del Obispado. Las invitadas, al parecer, fueron las ikastolas parroquiales del territorio pero también acudieron las demás, de modo que la asamblea contó con «representantes de todas las Ikastolas de Guipúzcoa».

72 Gipuzkoako Ikastolen Elkartea: Gipuzkoako Ikastolen Elkartea (1969-1994), Donostia, 1994. La Federación se constituirá como asociación de padres y ésa fue una razón clave por la que recibió críticas por parte de profesores de las ikastolas que tenían una orientación de izquierdas -precisamente los que se movían en torno a Gordailu-. 
de la Ley de Villar Palasí. Ésta supuso un enorme desafío y una auténtica encrucijada en la que se ponía en juego el futuro del movimiento de las ikastolas en un contexto en el que las dificultades internas (problemática religiosa, derechos de padres y niños/as, conflicto en torno a la unificación de la lengua, discusiones ideológicas y políticas) hacían complicada su evolución; algunas ikastolas asociadas incluso abandonaron la Federación aunque a mediados de la década de los setenta todas serán miembros socios de la misma, participando de un único proyecto y asumiendo idénticos principios: enseñanza en euskera, reglamento interno de carácter democrático, no tener ánimo de lucro, trabajar a favor de la cultura vasca en el ámbito de la enseñanza ${ }^{73}$. Ese es precisamente el hecho determinante que nos permite hablar de las ikastolas como movimiento social, como movimiento popular, también desde el prisma de los modos de organización de los que se dota: el surgimiento y evolución de las ikastolas guipuzcoanas demuestra que, desde su autonomía, estos centros, creando las estructuras organizativas que entienden eficaces, comparten, entre sí y con amplios sectores populares, un mismo proyecto educativo y escolar en torno a tres ejes comunes: el euskara, la cultura vasca y Euskal Herria (País Vasco).

\section{La mirada del Estado}

Finalmente, en la recta final de este trabajo, realizaremos una aproximación a la atención que despierta el fenómeno de las ikastolas, no ya desde la perspectiva de la afinidad, participación o complicidad con este auténtico terremoto que alterará definitivamente el paisaje escolar de Gipuzkoa $-y$, añadiríamos, del conjunto del País-, sino desde el prisma del régimen. La mirada de las estructuras del Estado -principalmente, la dirigida por el Gobierno Civil, auténtico centro de poder del franquismo en cada provincia- ${ }^{74}$ constituye, como se verá, un argumento para volver a reafirmarnos en la que entendemos incontestable definición del fenómeno de las ikastolas como movimiento popular.

En un periodo, el franquismo, en el que la persecución del euskera desde los orígenes del régimen, tal y como hace constar Euskaltzaindia-Real Academia de la Lengua Vasca-, llega incluso hasta las tumbas donde los nombres de los difuntos estaban escritos en este idioma ${ }^{75}$-dada su inequívoca «significación contraria a la unidad de la Patria»-76, no resulta complicado entender que la dictadura se

73 Ibidem, pp. I4-20. Tras la muerte del dictador la autorización, legalización y financiación de las ikastolas constituirán los ejes centrales sobre los que girará la labor de la Federación. Y en conjunción con el resto de Federaciones, entre otras cuestiones, reivindicará la cooficialidad del euskera o la creación de una Universidad Vasca, otra de las demoledoras carencias del País Vasco.

${ }_{74}$ El gobernador civil, representante directo del Estado en la provincia, asimismo jefe del Movimiento en la misma, ejerce un control directo sobre las instituciones locales -ayuntamientos y Diputación- y marca la presencia vigilante y ejecutiva del régimen en todos los sectores de la sociedad, también en el educativo.

75 Euskaltzaindia: Hizkuntza borroka Euskal Herrian, Bilbao, Ediciones Vascas, 1979, p. 36.

76 Orden del Ministerio de Justicia, i8 de mayo de 1938, en Torrealdai, J. M.: El Libro Negro del Euskera, Donostia, Ttarttalo, 1998, pp. 132-I33. En este trabajo, del que nos serviremos en las siguientes líneas, Torrealdai pretende hacer frente a la amnesia a la que condena ignorar, silenciar 
estrenara con especial virulencia también en el terreno escolar. Como señalábamos en la introducción, el franquismo se mostró implacable con aquellas experiencias y proyectos educativos en los que el euskera y la cultura vasca constituían sus pilares fundamentales; no podía ser de otro modo: en Euskal Herria, como en otras «regiones bilingües»-tal y como remarcaba Montagut desde la atalaya falangista del diario Solidaridad Nacional77, se producía una "secesión espiritual» que no podía enfrentarse sino con la prohibición absoluta «-y llevando la intransigencia a las medidas más radicales- toda explicación y enseñanza en cualquier idioma que no sea el castellano». Desde la misma inspección de Primera Enseñanza -por señalar algunas estructuras específicamente educativas- se señalaba al idioma -el «patrio»- como elemento fundamental de la educación nacional -española, claro- ${ }^{78}$ y desde la Dirección General de Primera Enseñanza se apuntaba al daño que «se hizo a la unidad de la Patria» desde el ámbito escolar ${ }^{79}$, ejemplos que de alguna manera marcan la medida de la inequívoca posición de la dictadura, posición que quedará recogida en la ley de 1945: «Es misión de la educación primaria [...] conseguir un espíritu nacional fuerte y unido e instalar en el alma de las futuras generaciones la alegría y el orgullo de la Patria, de acuerdo con las normas del Movimiento y de sus Organismos» ${ }^{80}$ y la escuela, en ese sentido -tal y como queda fijado en el preámbulo de la ley- «ha de ser esencialmente española» y el español - «lengua nacional»- lengua obligatoria en la enseñanza (art. 7) de la que quedarían excluidos, en los que hace referencia al País Vasco, tanto el euskera como la cultura vasca.

Situándonos en Gipuzkoa en el periodo en el que surgen y se desarrollan las ikastolas, y analizadas las memorias que anualmente se remiten desde el Gobierno Civil -donde se informa detalladamente de la situación que la provincia conoce en todos los órdenes-, se ha de constatar que a lo largo del mismo la preocupación fundamental del régimen la constituyen la situación política y los problemas de orden público -muchos de ellos derivados de la misma, pero también de la conflictividad laboral-. En la primera mitad de la década de los sesenta apenas si hay alguna mención directa en torno a la cuestión de las ikastolas -la primera de ellas no la encontraremos hasta 1965-; no obstante, la constante preocupación por lo que se denomina «movimiento vasco»-modo de referirse al nacionalismo vasco- puede brindar algunos elemento sugerentes para el análisis. En estos años son todavía pocas las ikastolas que darán sus primeros pasos, pero la dictadura muestra síntomas de preocupación respecto a una «provincia de marcadas tendencias sociales y políticas» y su posición no puede ser más clara y contundente: vigilancia especial en el caso del nacionalismo impidiendo «todo lo que suponga bandería

\footnotetext{
o infravalora la larga historia de «agravios» que ha padecido el euskera, historia que ni se inicia ni concluye con el franquismo y de la que tampoco las propias instituciones vascas han sido ajenas.

77 Montagut, J.: «El Estado Nacional frente al problema de la pluralidad de lenguas», Solidaridad Nacional, 6 de septiembre de 1939, en ibidem, pp. I45-I47.

$7^{8}$ MaIllo, A.: «Educación y Revolución. Los fundamentos de una educación nacional», en ibidem, 1943, pp. 159-160.

79 Ibidem, p. I6I. Estas manifestaciones, realizadas en julio de I945, corresponden a Romualdo de Toledo, director general de Primera Enseñanza.

8o «Ley de Educación Primaria de 1945», art. 6, BOE, n. ${ }^{\circ} 199$ de I8 de julio de 1945.
} 
política», conjugando control y censura, $\mathrm{y}$ «formación del espíritu nacional», tarea encomendada a la escuela y también a la Delegación Provincial de Juventudes $^{8 \mathrm{I}}$. Ciertamente, por apuntar un suceso significativo de gran impacto, la década se inicia con un acontecimiento relevante que generará una movilización social particularmente intensa en Gipuzkoa: la muerte del lehendakari Agirre en el exilio vendrá acompañada, como se constata por los servicios policiales correspondientes, por un desplazamiento de muchos simpatizantes guipuzcoanos al funeral celebrado en Donibane Lohitzune (San Juan de Luz, capital de Labort, una de la siete tradicionales provincias de Euskal Herria) y la posterior celebración de misas en muchos municipios del territorio vasco cuya finalidad política no escapa a las autoridades franquistas; en definitiva, síntomas de la "preocupante» orientación política de la provincia.

Si bien desde el Gobierno Civil se tratará de poner en evidencia «la adhesión inquebrantable de la Provincia» al régimen, personificado en el jefe del Estado, por ejemplo en el aniversario del «Alzamiento Nacional» ${ }^{82}$, muestra síntomas de que el sentir de Gipuzkoa es bien otro: la intensa actividad desplegada por el nacionalismo vasco -especialmente los sectores más jóvenes- ${ }^{83}$, que contaría con el apoyo incondicional del «clero separatista», dispara todas las alarmas. Además, se pondrá en evidencia que, con vistas al logro de la independencia de Euskadi, el euskera y el desarrollo del mismo por todos los medios constituyen un eje fundamental como preparación previa a la consecución de esa aspiración. Las intervenciones preventivas, también en prensa y radio, se llevan de manera permanente -tal y como reconoce el propio Gobierno Civil- pero, ya en el terreno escolar, resultaría evidente que «Guipúzcoa siente una gran necesidad de Escuelas de párvulos, principalmente teniendo presente que los niños comienzan a los 6 años la escolaridad sin conocer apenas la lengua española», preocupación ésta que será trasladada al Ministerio de Educación Nacional ${ }^{84}$. Esta preocupación, junto a la que provoca el recrudecimiento constante de las actividades políticas contrarias al régimen, se hace extensiva de forma particular, más allá de la edad de inicio de la escolarización, a los niños de zonas rurales no muy pobladas para quienes el «vascuence» constituye el medio de expresión habitual, el idioma que utilizan habitualmente, mientras que «encuentran dificultades en el uso del castellano» ${ }^{85}$.

Lo hasta ahora dicho se ha de interrelacionar con el hecho de que el dinamismo del nacionalismo vasco ${ }^{86}$ viene acompañado de un planteamiento ideológico en el que fundamenta las razones de la independencia del pueblo vasco en el

81 AGA, Memoria del Gobierno Civil de Guipúzcoa, rg6o, caj./leg. II.31о.

82 AGA, Gobierno Civil de Guipúzcoa, Informe sobre la actuación de las autoridades y corporaciones locales de esta provincia, durante el ejercicio de 196I, San Sebastián, 26 de abril de 1962.

83 Encuadrados en Euzko Gaztedi los «fieles» al PNV y en ETA los «disidentes».

$8_{4}$ AGA, Memoria del Gobierno Civil de Guipúzcoa, 196r, legajo IIзI8.

85 AGA, Memoria del Gobierno Civil de Guipúzcoa, I962, caj./leg. 44/II327.

86 A juicio del Gobierno Civil la actividad del PNv pasaría inadvertida, en tanto ETA despliega una gran actividad entre la juventud. Una de las preocupaciones que manifiesta es que ésta formula entre sus principales objetivos el de la creación de la Universidad Vasca, hecho comprobado con la desarticulación en 1963 de la organización clandestina de estudiantes EIB -Euzko Ikaslearen Batasuna-. 
hecho lingüístico, aun cuando esto no resulta ser contradictorio con que la Diputación Provincial asigne, desde 1963, subvenciones para sufragar los gastos de un profesor de vascuence en la normal de la capital, cátedra a la que se podrá asistir voluntariamente, con el propósito de «dotar a los futuros maestros de vocabulario con el que hacer frente en la escuela a las dificultades inherentes al bilingüismo en esta Provincia» ${ }^{87}$. Efectivamente hay una cuestión abordable desde un punto de vista instrumental, dada la concepción problemática que en torno a la realidad lingüística del territorio manifiesta el Gobierno Civil, a partir de la constatación de que hay niños, especialmente en zonas rurales, que desconocen el castellano y los maestros desconocen el euskera, frustrando, en ese sentido, una de las funciones básicas de la escuela. Pero, además, si algo pone en evidencia los planteamientos del Gobierno Civil es que cualquier clase de manifestación vasquista puede resultar peligrosa si, como ocurre con el nacionalismo vasco, que se muestra cohesionado - a diferencia de otros movimientos políticos- y con capacidad de penetración social (propaganda, reunión de masas, etc.)- se les da un carácter antiespañol, lo cual demanda una atención y vigilancia constantes. Incluso cuando son las autoridades locales quienes, «con la mejor intención», organizan fiestas de carácter vasquista "para exaltar el folklore y las costumbres vascas» no se restaría el carácter contraproducente de las mismas toda vez que el nacionalismo, también en esas circunstancias, así como en actos organizados por asociaciones deportivas o religiosas, las instrumentalizaría "para agrupar a sus afiliados y levantar su espíritu nacionalista». En ese contexto, desde el Gobierno Civil se destaca el esfuerzo desplegado por el nacionalismo vasco con la finalidad de divulgar la enseñanza y práctica del euskera, a la vez que plantea que la solución al respecto pasaría -en clara actitud subversiva- por la consecución de un nuevo marco jurídico-político que permitiera hacer efectivo el bilingüismo en la enseñanza; y ése es, en clara referencia a las primeras ikastolas, ya en 1965 , el escenario donde toma cuerpo la preocupación del régimen: «Cada día aparecen más escuelas donde se enseña casi exclusivamente en vascuence» ${ }^{88}$.

Sin embargo, no podemos sino constatar que el régimen no está libre de contradicciones - por no mencionar el hecho de que se inhibe cuando no percibe riesgo alguno- y muestra, en algunas ocasiones, una posición pendular; ciertamente se muestra prevenido ante la posibilidad de que la enseñanza del euskera sirva de arma de penetración del nacionalismo vasco, pero a la vez es consciente de que la realidad lingüística de Gipuzkoa demanda respuestas desde el ámbito de la enseñanza. En ese sentido resulta significativo que, por ejemplo, la Inspección de Enseñanza Primaria de la provincia, atendiendo el acuerdo adoptado por

\footnotetext{
${ }_{87}$ AGA, Memoria del Gobierno Civil de Guipúzcoa, 1963, caj./leg. 44/II459. Diputación Provincial de Guipúzcoa.

88 AGA, Memoria del Gobierno Civil de Guipúzcoa, 1965, caj./leg. 44/II689. El informe que se remite a las autoridades centrales del Estado pone de manifiesto que la acción subversiva en la provincia gira alrededor del nacionalismo vasco que ya a mediados de la década habría incrementado de forma ostensible la propaganda clandestina. Además haría uso de otros medios: fomentar, al parecer de manera exitosa, las manifestaciones populares, fiestas vascas, concentraciones, reuniones de montaña, teatro y conferencias literarias, dándoles un carácter legal aparente pero encubriendo «separatismo».
} 
la Diputación, eleve a la Dirección General de Enseñanza Primaria la propuesta de que los «Maestros Nacionales» pudieran impartir, fuera del horario escolar, cursos de euskera argumentando que se estuviera perdiendo por efecto de la inmigración, concretamente en las zonas urbanas; eso sí, con la garantía de que las clases de euskera estarían controladas por la Inspección Estatal de modo que no se utilizaran para otros fines ${ }^{8}$. El propósito de la Diputación, no obstante, sería bastante más ambicioso; interpreta que las subvenciones a la Normal responderían a la idea de «formar en el conocimiento del vascuence a los Maestros Nacionales para que en su día pudiera ser el vehículo de la enseñanza del idioma a las nuevas generaciones» ${ }^{\circ}$. Desde la Inspección no se recoge, ni mucho menos, esta aspiración, pero sí muestra la conveniencia de ejercer cierto control ${ }^{91}$ respecto a un universo nuevo que comienza a cobrar unas dimensiones significativas y cuyas consecuencias pueden resultar inconvenientes al régimen, régimen que padece, en Gipuzkoa, una actividad subversiva intensa, razón por la que se solicita el incremento en los servicios de la Guardia Civil muy especialmente "por asuntos políticos de matiz nacionalista o vasco-separatista ${ }^{92}$. La sospecha es que entre esos asuntos pueda encontrarse el de la creación de ikastolas, toda vez que «pudieran» no avenirse con la «formación del espíritu nacional» y el reconocimiento del español como «lengua nacional»-principios que reiteradamente son recogidos por la legislación educativa93 ${ }^{93}$ explicaría la inquietud por el hecho de que proliferaran escuelas no autorizadas «en las que se imparte la enseñanza en vascuence, dirigidas por personal sin título y en gran parte politizado» ${ }^{94}$.

El estado de excepción decretado en Gipuzkoa en 1968 -que tendrá su continuidad al año siguiente-9s brinda un contexto en el que la situación convulsa de la provincia, con numerosos registros, detenciones, incautaciones..., por parte de las Fuerzas de Orden Público, acompaña a la que desde el Gobierno Civil se interpreta como «una de las labores más importantes realizadas por la Inspección de Enseñanza Primaria», a saber, una función específica de control: «la tramitación de expedientes relativos a la legalización de escuelas e "ikastolas" que no se hallaban en situación reglamentaria en esta provincia». En este sentido el Gobierno Civil pretenderá en el ámbito de la enseñanza no estatal que todas las

89 Inspección de Enseñanza Primaria de Guipúzcoa: Informe dirigido al Ilmo. Señor Director General de Enseñanza Primaria, ADG (Archivo de la Diputación de Guipúzcoa), 1966, I390.

90 Diputación Provincial de Guipúzcoa: Acuerdo del pleno de la Corporación de fecha 25 de octubre sobre el establecimiento de clases de vascuence en las Escuelas de la Provincia, ADG: Libro de Actas, 1966.

9r Ya la obligatoriedad del Libro de Escolaridad (Ley de 2I de diciembre de 1965) establecía un mecanismo de control que -si bien no fue motivado por su existencia- tuvo sus consecuencias en las ikastolas existentes, provocando, por su capacidad adaptativa, su «ocultamiento», principalmente por la colaboración de maestros/as de las escuelas nacionales, lo que no facilitaba un férreo control.

92 Gobierno Civil de Guipúzcoa: Memoria de gestión correspondiente al año 1966, San Sebastián, 27 de febrero de 1967, AGA, caj./leg. 44/12138.

${ }_{93}$ «Decreto 193/1967 por el que se aprueba el texto refundido de la Ley de Enseñanza Primaria», $B O E, \mathrm{n}^{\circ} 37$ de $\mathrm{I} 3$ de febrero de 1967.

94 Gobierno Civil de Guipúzcoa: Memoria del año 1968, San Sebastián, abril de 1969, AgA, caj./leg. 32/II435.

${ }_{95}$ Como es sabido en enero del 69 se decretará para todo el Estado quedando derogado en marzo. 
escuelas se sometan a un proceso de verificación que permitiera su legalización y, en ese sentido, lograr la «normalización» del escenario escolar guipuzcoano ${ }^{96}$. Además, planteará una solución, que si bien no resulta novedosa - preparar Maestros Nacionales que dominen el euskera-, ahora se plantea específicamente como medio de enfrentar el problema que suponen las ikastolas; el Gobierno Civil no puede manifestarse de forma más clara refiriéndose al peligro nacionalista: «Se han manifestado también en esta provincia infiltraciones en la labor educadora, especialmente a través de las “ikastolas”»97. Propondrá también, con carácter de urgencia, fuertes inversiones por parte del Estado en construcciones escolares y profesorado adecuado en todos los niveles educativos y vigilar las subvenciones que no deberían concederse, en clara referencia a las ikastolas sospechosas, sin previo informe de la Autoridad gubernativa. La implicación del Estado se estima fundamental, entre otras razones, "para evitar infiltraciones de tipo político, inconveniente a la labor educativa por parte de organizaciones de tendencias conocidas e incluso por parte del clero que en bastantes supuestos está realizando una influencia de franca desviación ideológica, desde el punto de vista político y social» ${ }^{98}$.

El final de la década de los sesenta, como vemos, está caracterizado por un celo notable por controlar la actividad de las ikastolas y se cursarán, en ese afán por vigilarlas, circulares a los ayuntamientos solicitando comunicación al Gobierno Civil sobre cualquier tipo de iniciativa para abrir o ampliar centros de enseñanza -claramente los que escapaban a su control eran ese tipo de centros-, de modo que se observara y detectara la eventual apertura de centros de enseñanza primaria sin la reglamentaria autorización. Nuevamente el de las ikastolas - «escuelas en que se imparten enseñanzas sin garantías»- constituye durante el último año de los sesenta uno de los principales problemas de la enseñanza en la provincia, a la vez que se constata la demanda-reforzada por el deseo de diferentes sectores interesados en la conservación del euskera- de escuelas bilingües; por parte del Gobierno Civil no se valora la conveniencia de la conservación de la lengua, pero sí se señala -en la línea que hemos venido subrayando- la necesidad de preparar maestras bilingües, pero en párvulos y en los casos en los que se estimara necesario, como mera fase de transición hacia el aprendizaje del castellano ${ }^{99}$.

Los últimos años del régimen, además de por un alto nivel de conflictividad laboral donde el movimiento obrero dará muestras de una gran fortaleza, estarán marcados en Gipuzkoa -también en el resto del País- desde un punto de vista político por el Consejo de Burgos (1970); la muerte en atentado de Carrero Blanco

${ }_{96}$ La legalización de cualquier centro escolar pasa necesariamente por contar con la autorización expresa del Ministerio para lo que necesariamente, entre otros, es indispensable superar el «filtro» del Gobierno Civil que es quien cuenta, entre otros, con los pertinentes informes de la Guardia Civil.

${ }_{97}$ Gobierno Civil de Guipúzcoa. Memoria del año 1968, San Sebastián, abril de 1969. AGA, caj./ leg. 32/II435.

${ }_{98}$ Ibidem. Si bien no es nueva esta posición llama la atención la contundencia a la hora de referirse a esa parte del clero: «Verdadero cáncer de las provincias vasco-navarras y causa de todo el mal separatista».

99 Gobierno Civil de Guipúzcoa: Memoria del año 1969, San Sebastian, i. 일 de marzo de 1970, AGA, caj./leg. 52/483. 
(1973), presidente del Estado; los fusilamientos de septiembre del 1975 y el fallecimiento, ya anciano, del dictador Franco ese mismo año. Este contexto general se completará, en el ámbito de la enseñanza, con la Ley General de Educación del 1970, que supondrá para las ikastolas un antes y un después en un proceso histórico de crecimiento de difícil retorno en el que los condicionantes, especialmente, de carácter político, junto a los socioculturales, actuarán de combustible del mismo. Así, la década se inicia, en lo político, con una situación -influida por la proximidad del Consejo de Guerra de Burgos- cuya gravedad, desde la perspectiva del Gobierno Civil, no se había conocido «desde la Guerra de Liberación ${ }^{\text {»0o, }}$ en la que el régimen da muestras de una furia inusitada. Y en lo educativo con un síntoma relativo de apertura en el que la Ley de Villar Palasí abre la posibilidad del aprendizaje de las «lenguas nativas» dado que entre sus fines contempla «la incorporación de las peculiaridades regionales, que enriquecen la unidad y el patrimonio cultural de España» ${ }^{101}$, a la vez que marca un nivel de exigencia respecto a las condiciones que necesariamente habían de cumplir los centros educativos a las que las ikastolas tendrán que responder, transformando un momento crítico en una oportunidad de desarrollo y fortalecimiento.

Desde el Gobierno Civil, y en consonancia con la alarma política con la que el régimen se enfrenta a estos tiempos, se plantea la necesidad de enfrentar el desarrollo de la cultura y la enseñanza buscando además «el resultado político más apropiado, teniendo en cuenta la especial sensibilidad de esta Provincia $»^{102}$; en este contexto se entiende la reiterada preocupación de construcción de «Escuelas Nacionales» -extremo éste que se vivirá como amenaza por parte de las ikastolasy el lamento por el retraso en su realización toda vez que se constata un movimiento acentuado de, en clara referencia a las ikastolas, «iniciativa privada a través de Cooperativas de Padres de Familia para ir ellos a la edificación de nuevos centros $»^{103}$. La interpretación que desde el Gobierno Civil se realiza al respecto es muy transparente: «Es de señalar que en esta Provincia la incidencia excesiva de la iniciativa privada en la instalación de Centros de Enseñanza implica un peligro real de que se aprovechen los mismos para impartir o influir tendencias políticosociales desviacionistas» ${ }^{104}$. En línea con esa preocupación, demandará del Gobierno del Estado el aumento del número de inspectores -algunos de los cuales convendría que conocieran el euskera- para controlar eficazmente la problemática que se detecta en Gipuzkoa tanto en preescolar como en la EGB, «sobre todo teniendo en cuenta las desviaciones políticas que las denominadas Ikastolas llegan a plantear, por su sistema de Enseñanza a base del monolingüismo del euskera» ${ }^{105}$

${ }_{100}$ Gobierno Civil de Guipúzcon: Memoria de la Provincia correspondiente al año I97o, San Sebastián, 30 de marzo de I97I, AGA, caj./leg. 52/497.

ıо Ley General de Educación, art. I,3.

102 Gobierno Civil de Guipúzcoa: Memoria de la Provincia correspondiente al año I97I, San Sebastián, abril de 1972.

ro3 Gobierno Civil de Guipúzcoa: Memoria de la Provincia correspondiente al año I973, San Sebastián, marzo de 1974 .

${ }_{104}$ Ibidem.

ros Gobierno Civil de Guipúzcoa: Informes a la Subsecretaría del Ministerio de Educación y Ciencia de I y 26 de diciembre de I973, y i de febrero de 1974. En cualquier caso, las ikastolas no 
(desde el Gobierno Civil se llega a solicitar incluso que se aclaren y regulen aspectos de la Ley de Educación referidos a las lenguas nativas en tanto se da lugar a «desviacionismos» como en los que incurren las ikastolas) $)^{106}$.

Un año antes del fallecimiento de Franco el gobernador civil advertía al Ministerio de Educación y Ciencia del peligro que suponía la situación del ámbito de la enseñanza no estatal y más concretamente en el campo de las ikastolas, señalándose la importancia de que en las escuelas nacionales hubiera profesorado que dominara el euskera «con objeto de que la enseñanza estatal no se vea repudiada por los nativos de la provincia» ${ }^{107}$; el propio gobernador liga la conflictividad de la provincia con la urgente necesidad de que desde el propio régimen se den respuestas educativas eficaces intentando desarrollar el campo de la enseñanza estatal. En resumen, iniciativa privada «excesiva», en tanto políticamente peligrosa ${ }^{108}$, que el propio Gobierno Civil calificará como movimiento en clara alusión a las ikastolas que toman la iniciativa de creación y construcción de centros escolares en los que el euskera y la cultura vascas, como hemos venido repitiendo, son su señas de identidad, como alternativa a la política educativa del Estado. La muerte del dictador abrirá las puertas al proceso de lo que se ha dado en denominar transición democrática, periodo en el que si bien no desaparecerán las sospechas respecto al movimiento de ikastolas -tampoco las agresiones- posibilitará, una vez aprobada la Constitución de 1978, la conformación de un marco político -el Estatuto de Gernika para el caso guipuzcoano- en el que éstas contarán con un suelo legal en el que poder desenvolverse, ya sin la amenaza de la dictadura franquista, aun cuando no se verán libres de otras series de ataques y maniobras intimidadoras que someterán a las ikastolas a la necesidad de sortear riesgos de forma regular poniendo al movimiento popular que las ha sostenido históricamente en un estado de activación permanente.

carecen de ingenio para escapar al control de la inspección, dándose el caso -como relata alguno de nuestros testigos, maestros para mayor precisión- de contar con profesores retirados «en reserva» que pudieran brindar un perfil más «pertinente» en las visitas que realizaban los inspectores de enseñanza.

106 Esta cuestión conocerá un desarrollo legislativo a lo largo de los setenta pero la presencia de las llamadas lenguas regionales en la enseñanza no tendrá vuelta atrás; en cualquier caso, se reservará la calificación de lengua nacional al español.

${ }_{107}$ Gobernador Civil de Guipúzcoa, Escrito remitido al Ministerio de Educación y Ciencia, San Sebastián, 5 de junio de 1974. A juzgar por los testimonios que hemos tenido ocasión de analizar, el gobernador civil leía finamente el sentir de gran parte de la ciudadanía.

${ }_{108} \mathrm{La}$ preocupación por las tendencias «antiespañolas» se hacen extensivas a los centros educativos atendidos por religiosos, en línea con la percepción que desde el Gobierno Civil se tiene del clero filonacionalista, mayoritario en la provincia. 